\title{
SOCIAL CAPITAL AS A DETERMINANT OF THE SHADOW ECONOMY IN THE REPUBLIC OF SERBIA
}

\author{
Natasa Golubovic* and Marija Dzunic \\ Faculty of Economics, University of Nis, Nis, The Republic of Serbia
}

\begin{abstract}
The design and implementation of the measures aimed at incorporating informal economic activities into the existing formal regulatory framework assume the knowledge of the causes and structure of the informal activity. The influence of the institutional factors that encourage the development of the shadow economy (the tax burden, the degree of the regulation of the economy, the capacity of the state administration) were the subject of extensive theoretical and empirical research. In contrast, the impact of social capital, i.e. the characteristics of social ties and relations, on the shadow economy has been investigated to a much lesser extent. Starting from the fact that the informal sector of the Serbian economy is so widespread that it represents a serious obstacle to the business activities of Serbian enterprises, the aim of this study is to investigate whether the characteristics of social ties and relations, or social capital in the Republic of Serbia (RS), represent a fertile ground for the growth of the shadow economy. In this context, the characteristics and frequency of social contacts, particularized trust and institutional trust will be separately analyzed as the determinants of the shadow economy in RS.
\end{abstract}

Keywords: social capital, social networks, trust, shadow economy

JEL Classification: E26, O17, Z13

\section{INTRODUCTION}

The shadow economy is the research subject of various disciplines, ranging from economics, anthropology, political science, sociology. The key issues in the study of this phenomenon in economic science are related to the size and structure of the shadow economy, its causes, effects on productivity and prosperity, and the impact on economic growth, poverty and inequality.

\footnotetext{
* Correspondence to: N. Golubovic, Faculty of Economics, University of Nis, Trg Kralja Aleksandra 11, $18000 \mathrm{Nis,}$ The Republic of Serbia; e-mail: natasa.golubovic@eknfak.ni.ac.rs
}

Although the shadow economy provides livelihoods to millions of people and represents a kind of a "safety net" for many individuals and families, its adverse effects on the economy and society significantly exceed its positive effects.

The measures aimed at the incorporating of the shadow economy into the existing regulatory framework flows are based on the knowledge of the causes and structures of the informal activity. In this regard, a special problem is the fact that data on informal activities are unreliable and incomplete. The shadow economy is a complex entity, composed of a number 
of different activities, whose measurement represents a serious challenge.

Since informal transactions rely on social ties, exploring ways in which social networks work is important for a more complete understanding of the underground economy. The social capital of the former socialist economy is characterized by an abundance of social networks that are built in order to overcome shortages of goods and services. These same connections are now used, along with other resources, for the purpose of solving problems in the market economy. Informal economic transactions continued to play an important role in the transition period, filling the gap that appeared as a result of the collapse of the existing institutions of the socialist economy and the slow emergence of the market economy institutions (Busse, 2001).

The aim of this study is to investigate whether the characteristics of social ties and relationships, or social capital in RS, represent a fertile ground for the growth of the shadow economy. In this analysis, we start with the assumptions that the frequency of social contacts and mutual (particularized) trust promote the growth of the shadow economy, while institutional trust has a negative impact on the growth of the shadow economy. The exploration of the level of available social capital, in terms of the intensity of social contacts, the density of social networks and the existing level of mutual and institutional trust, will be based on the data obtained from the Third Quality of Life Survey in Europe (Eurofound, 2012), while - as the measure of the shadow economy - we will use data on the perceptions of the business community regarding the extent of the shadow economy in RS, which are the result of the fifth wave of the Business Environment and Enterprise Performance Survey - BEEPS V, conducted by the European Bank for Reconstruction and Development (EBRD, 2015). Starting from the existing research of the impact of social capital on the shadow economy, the analysis of social capital will include the quantitative aspect of social relations, in terms of the intensity of informal social contacts in social networks, as well as the qualitative aspects of social capital, in the sense of the levels of specific types of trust, relevant for encouraging or restricting informal economic transactions. At the end of the paper, the key research findings will be presented.

\section{LITERATURE REVIEW}

There is no single definition or indicator of the shadow economy. The shadow economy is usually defined as a set of economic activities which take place outside the institutionalized economic environment. If the formal economy is perceived as the set of all registered economic transactions, then the shadow economy involves all economic transactions that go unrecorded, untaxed, unregulated and without appropriate licenses (Thomas, 1992; Portes, 1995). It is also called the informal economy, the irregular sector, the black market etc. the economic activity described with these terms is irregular in the sense that individuals who are engaged in it, either as buyers or as sellers, are trying to hide this activity from the state. They do this in order to avoid the obligation to obtain permits necessary for engaging in this activity, and to avoid regulations and taxes.

In developing countries, the shadow economy accounts for over one half of the economic activity. It provides livelihoods to millions of people. However, its role in economic development remains controversial. Some, like H. de Soto (2000), see the untapped reservoir of entrepreneurial energy in companies operating in the shadow economy, which is inhibited by the state regulation. In this respect, easier market access and a better definition and protection of property rights will release that energy, which will foster economic growth and development. Others, such as S. Levy (2008), point out the darker side of the shadow economy, which is related to the advantages that these companies enjoy by avoiding taxes and regulations. The report of the McKinsey Global Institute portrays enterprises in the shadow economy as parasites that represent disloyal competition to enterprises in the regular economy, operating in compliance with the current legislation (McKinsey, 2004).

The shadow economy negatively affects economic efficiency. First, it increases transaction costs because customers need to devote more time to complete their 
transactions, cross a greater distance to accomplish the exchange and the like. Also, in the exchange process, customers often receive goods of a lower quality, as well as goods without a guarantee (which goes with the goods produced in the legal economy). By moving into the shadow economy, enterprises are in a position to circumvent safety and environmental standards, meaning that, because of a higher risk that consumers and employees are exposed to, as well as due to negative external effects on the environment, social welfare is reduced. Workers employed in the shadow economy do not pay social security and healthcare contributions, which has wider implications in terms of poverty and inequality. Further, the state loses revenue from taxes and permits that would otherwise be collected. This loss may compel the state to increase tax rates or introduce additional taxes to cover its costs, leading to new distortions and a new transition of activities into the shadow economy. This is particularly important for countries facing the challenge of fiscal consolidation, such as RS. We should add that all those who participate in the underground economy violate a certain law or regulation, and probably some customs of the local community. Anyone who violates a particular law and goes unpunished may be tempted to violate other laws. In this way, the moral structure of the community could be undermined.

The research into the causes of the shadow economy is mainly concentrated on two factors:

- institutional factors, and

- relationships between individuals, as well as relationships between individuals and the state.

The first group of factors is related to the institutional conditions that stimulate the growth of the shadow economy. Within this group of factors, effects of the degree of the regulation of the economy, the tax burden and the capacity of the state administration are usually analyzed. When deciding whether to move into the shadow economy or not, the rational actor compares the benefits of operating in the shadow economy and a potential cost in the form of a penalty he/she would pay if caught. Taxes and other forms of the state regulation could reduce economic efficiency and social wellbeing through the deformation of a choice between different goods, between work and leisure etc. They also affect the choice of performing a certain activity in the regular or in the shadow economy. The relatively large informal sector could be explained by high costs of regulation and taxation, borne by individuals and businesses, for which they have benefits if they move into the shadow economy, and small penalties if caught. These findings are confirmed by the results of the analysis by S. Johnson, D. Kaufmann and P. Zoido-Lobaton (1998), performed on the sample of 49 countries (Latin America, the former Soviet Union and the OECD), that the shadow economy is higher if there is a higher degree of the regulation of the economy, a higher tax burden, the weaker rule of law, a higher level of the corruption of the state bureaucracy. The first two sets of variables are commonly used as a measure of benefits from the transition to the shadow economy in order to avoid interference by the state and taxation. The other two are associated with the probability of detection and punishment. The weaker the rule of law is and the more corrupt the state officials are, it is more likely that the law can be bypassed or the state officials bribed in order to avoid punishment.

The second group of factors is related to social ties, i.e. to the exploration of the impact of social capital, first of all of social networks, mutual trust and trust in institutions. Social capital plays an important role in carrying out transactions in the shadow economy. The more the shadow economy is getting closer to the model of a real market, the more it is dependent on social ties in its functioning (Portes, 1994, 430). A significant portion of economic transactions in the shadow economy presupposes the existence of social networks, or some kind of social capital. The emergence and growth of the shadow economy, according to L. Burroni, C. Crouch, M. Kaminska and A. Valzania $(2008,487)$ cannot be explained only by economic pressures. An important role is played by the weakness of public institutions, high levels of organized crime, the specificity of the institutional framework, the quality of implementation mechanisms, the low levels of institutional trust and the high level of particularized (mutual) trust. A. Portes (1998) also indicates the set of factors that encourage informal activities, and refers to the quantity and quality of social relations. The quantitative aspect of social 
relations is the closest to the classical approach to social capital, where social relationships are perceived as a resource. Social relations, rather the characteristics of social relations that enable economic actors to achieve their goals, are at the base of the social capital concept. As the core of the social capital concept, A. Portes (1998, 6) emphasizes the ability of actors to secure benefits on the basis of their memberships in social networks or other social structures. In this sense, social capital means the totality of current and potential resources that a particular social group can mobilize through its members. Social capital, however, differs from other forms of capital because it is an integral part of social relations, rather than actors themselves (Coleman, 1990).

Although social networks are usually explored in an affirmative context, they can produce negative effects as well (Portes \& Landolt, 1996). According to P. Dasgupta (2000, 390), social networks can provide an incentive or a hindrance, depending on the reasons why they have emerged. If an individual has a dense network of relationships with other individuals, it increases the opportunity for him/her to connect with those actors who are able to implement informal transactions. In other words, the number and frequency of social contacts encourage an involvement in informal activities. The assumption that the density of social networks is proportional to the number of informal transactions is based on higher overall transaction costs of informal exchange. The costs of collecting information in order to carry out informal transactions are higher because, in the absence of communication through the media and advertising, participants in informal transactions depend on friends, relatives and acquaintances. J. Field $(2003,83)$ notes that it is necessary to distinguish between productive social networks, which produce positive effects for the members and the community in general, and social networks that have positive effects for the members, but negative ones for the wider community. Exploring the social networks in Netherlands, R. Kloosterman, J. van der Leaun and J. Rath (1999) have found that many immigrants who come to the Netherlands, in the absence of financial resources and appropriate education and qualifications, do not have many options available. In order to survive in competitive markets, they turn to informal economic activities that depend on specific social networks - mostly based on ethnic ties. In these cases, where informal activities are a direct consequence of limited opportunities in the formal labor market, social capital plays an important role.

In centrally-planned economies, transactions on the black market represented a mechanism for solving problems related to the shortage of goods and services in the regular economy (Millar, 1987; Grossman, 1989). Scarcity and the presence of corruption have forced citizens to use informal ties to perform everyday transactions, such as buying products, receiving medical care, obtaining loans etc. The informal networks developed during that period were essential for everyday life. In the socialist period, individuals built networks with a circle of people who they could trust. Those small networks allowed them to cope with difficulties in their daily lives, obtain scarce goods and help close friends, relatives and neighbors (Ledeneva, 1998). The aforementioned networks, which played an important role in former socialist economies, served as a substitute for broader social networks that could not exist in repressive regimes (Ledeneva, 1998; Flap \& Voelker, 2003).

Informal economic transactions continued to play an important role in everyday life in the transition period. Despite the development of formal institutions, formal and informal economic transactions continue to coexist in these countries. As an example, we can cite rental apartments, which can be rented through an agency, as well as through informal channels. Another example is currency trading on the black market, outside banks and authorized exchange offices. Even when formal institutions exist, individuals still rely on informal arrangements because it is easier, cheaper, more profitable (at least in the short term), and there are fewer barriers to entry.

In addition to the number of social contacts, the qualitative dimension of social relations also plays an important role in informal exchange. The qualitative dimension of social capital is related to trust and is often referred to as the cultural dimension of social capital (Van Deth, 2003). Trust plays a role similar to the one played by social ties - reducing transaction 
costs. This role is even more pronounced in the case of informal transactions in relation to formal ones because, in the absence of formal mechanisms for contract enforcement (police, courts), individuals are referred to mutual trust. Mutual trust serves as a guarantee that participants in informal transactions will not report each other to the police. A. Portes (2010) cites the example of close ties in the Jewish community in Georgia, the former USSR. Many of them were successful entrepreneurs in the shadow economy, bypassing the centralized economy. This was possible owing to strong mutual trust, embedded into solid networks based on the common descent and culture.

We have to point out the difference between generalized and mutual trust. Generalized trust represents ex ante willingness to cooperate, or perform transactions with an anonymous second party. Mutual trust refers to trust within a group of interconnected individuals, based on the profession, the gender, political or religious beliefs, the racial or ethnic background. Social groups can create a high level of internal solidarity and trust. However, many groups achieve internal cohesion at the expense of others, who are treated with suspicion and distrust, producing significant negative external effects for the society in which they operate (Fukuyama, 2000). In this case, the high level of trust within the group coincides with the weakening of trust toward other individuals in the society. The economic advantages of social networks are being undermined by the inability to establish the so-called "bridging" ties between individuals in different social groups, leading to the formation of closed, parochial networks (Fukuyama, 1995; Castells, 1997). In addition to parochialism, another cause for concern relates to the tendency of networks to encourage secrecy and coverup, which undermines respect for the law and order. So, the existing social networks actually encourage corruption and opportunistic behavior, rather than economic efficiency.

In addition to mutual trust, institutional trust is also important. When trust in institutions is low, pressure on civil servants to perform their duties better and more responsibly is weak. As the level of trust increases, public pressure on the state employees also rises, creating prerequisites for more efficient public management and business environment that is conducive to the economic activity (Lekovic, 2012, 65-78). There is an inverse relationship between institutional trust and informal transactions. If the majority of citizens in a society perceive the existing institutions as fair and impartial, then trust in formal institutions that govern transactions prevails in such a society. A high level of trust in institutions discourages individuals from engaging in informal transactions. On the other hand, if the government regulation is perceived as intervention in areas where the state should not intervene, the erosion of trust in the state institutions occurs, leading to their gradual loss of their legitimacy. In such circumstances, actors are willing to participate in informal activities. The perceived quality and legitimacy of the state interference in the economy affects the propensity of actors to participate in informal activities. We see that trust can have a twofold impact on the informal sector. It is assumed that a high level of mutual trust affects the growth of the underground economy, whereas higher levels of institutional trust have a negative effect on the size of the informal sector.

\section{METHODOLOGICAL FRAMEWORK AND DATA SOURCES}

In order to examine the potential impact of social ties and relations on informal economic transactions in RS, empirical data obtained from two surveys will be used in this paper. Investigating the level of available social capital, in terms of the intensity of social contacts, the density of social networks and the existing level of individual and institutional trust, will be based on the data obtained from the Third European Quality of Life Survey (Eurofound, 2012), conducted in EU27 member states, as well as seven of the nine countries which at that time were involved in the enlargement process (Croatia, FYR Macedonia, Iceland, Kosovo, Montenegro, The Republic of Serbia and Turkey). The European Quality of Life Survey is a representative survey conducted by the European Foundation for the Improvement of Living and Working Conditions, which is a rich source of data on living conditions, housing, the local environment, health, public services, social cohesion and the quality of the society, as well as subjective well-being. For the purposes 
of this paper, the data relating to the sub-sample of 1002 households in RS, collected during 2012, will be analyzed. With the aim of comparing the level of social capital in RS with the neighboring countries and the $\mathrm{EU}$, the data on the individual components of social capital in Croatia, Montenegro and FYR Macedonia, as well as the average value for the $27 \mathrm{EU}$ countries, will be presented.

Given the fact that the measurement of the shadow economy is accompanied by objective methodological problems, there is no universally accepted method of measuring the shadow economy in scientific research that would offer absolutely reliable and complete information. In this regard, a variety of different models of the assessment of the gray economy have been developed (Krstić, Schneider, Arandarenko, Arsić, Radulović, Ranđelović, Janković, 2013). Most often, the estimates are carried out at the macroeconomic level, and include an assessment of the share of the shadow economy in the GDP (Schneider, Buehn, \& Montenegro, 2010). However, due to the nature of informal activities that involves secret, hidden and implicit transactions, economic actors' perceptions of the intensity of transactions in the informal economy appear as a potentially important source of information. The measurement of social phenomena based on subjective perceptions of the respondents is equally burdened with numerous dilemmas, primarily due to the absence of the value neutrality and the objectivity of the respondents, which calls into question the accuracy of the collected data. Nevertheless, for a whole range of contemporary social phenomena, such as corruption, the shadow economy, trust, the quality of the state institutions and the like, exploring the subjective perceptions of individuals' is a common and widely accepted method of measurement. In this sense, the measure of the shadow economy used in this paper will be based on the data on the business community's perceptions of the spreading of the informal economy in RS. The data were collected through the fifth wave of the Business Environment and Enterprise Performance Survey - BEEPS $V$, conducted by European Bank for Reconstruction and Development (EBRD, 2015). The survey was periodically conducted since 1999, on the basis of interviews with the managers of the firms in order to assess the quality of the business environment and the main challenges in the development of the private sector. The fifth wave of the survey was conducted on a sample of 15,883 companies in 30 countries of Eastern Europe and Central Asia, and in this paper, the data obtained from 360 companies in RS, collected in the period from January to August 2013, will be used. The ownership structure of the analyzed companies includes 317 companies 100\%-owned by domestic private capital, 25 companies $100 \%$-owned by foreign capital, 10 companies with a certain percentage $(1 \%$ $93 \%$ ) of the state capital, and 8 companies of a mixed ownership. The study included all types of companies - micro, small, medium and large.

The analysis of the empirical data at the level of social capital includes the quantitative aspect of social relations, as the intensity of informal social contacts in social networks; and the qualitative aspects of social capital, in terms of the levels of the specific types of trust, relevant for the facilitation or restriction of informal economic transactions. Exploring the level of the shadow economy in RS will be based on an analysis of the business community's perceptions of unfair competition from the informal sector and the informal economy as one of the key obstacles to doing business.

\section{SOCIAL CAPITAL AND THE SHADOW ECONOMY - EMPIRICAL DATA}

\section{Social capital within social networks}

The participation of individuals in formal and informal social networks is the basic indicator of the network dimension of social capital. Measuring the level of participation in formal networks (different community organizations) is based on the survey questions about belonging to a variety of voluntary associations and an active participation in their activities. Table 1 shows the frequency of social contacts of the citizens in the form of activities within various clubs, societies and associations. Participation in this kind of social networks enables access to information, discovering new opportunities and an advancement in society. Based on the data on participation in formal networks, 
Table 1 Social ties within formal networks (participating in the activities of a club, a society or an association)

\begin{tabular}{l|cccccc}
\hline & $\begin{array}{c}\text { The Republic of } \\
\text { Serbia }\end{array}$ & FYR Macedonia & Montenegro & Croatia & $\begin{array}{c}\text { Average } \\
\text { Balkans }\end{array}$ & Average EU 27 \\
\hline $\begin{array}{l}1 \text { Every day or } \\
\text { almost every day }\end{array}$ & $3.0 \%$ & $1.4 \%$ & $1.9 \%$ & $4.1 \%$ & $2.8 \%$ & $2.5 \%$ \\
2 At least once a & $5.7 \%$ & $4.4 \%$ & $4.7 \%$ & $9.7 \%$ & $6.2 \%$ & $12.3 \%$ \\
week & $6.0 \%$ & $6.9 \%$ & $4.2 \%$ & $6.9 \%$ & $6.1 \%$ & $10.3 \%$ \\
$\begin{array}{l}3 \text { One to three } \\
\text { times a month }\end{array}$ & $14.1 \%$ & $14.0 \%$ & $21.7 \%$ & $14.1 \%$ & $16.1 \%$ & $15 \%$ \\
4 Less often & $71.0 \%$ & $73.1 \%$ & $65.8 \%$ & $64.7 \%$ & $68.8 \%$ & $59.8 \%$ \\
\hline Never & 4.45 & 4.53 & 4.47 & 4.26 & 4.43 & 4.17 \\
\hline $\begin{array}{l}\text { Mean value of } \\
\text { indicator (1-5) }\end{array}$ & & & & & & \\
\hline
\end{tabular}

Source: Eurofound, Third European Quality of Life Survey, 2012.

it can be concluded that over $70 \%$ of Serbian citizens never engage in this kind of social contacts. Looking at the different categories of frequency, it is notable that participation in formal networks falls within the specific terms of countries in the region, but is far behind the EU countries. The average value of the frequency indicators clearly confirms the fact that the intensity of social contacts of the citizens of RS within formal networks is low.

In addition to the engagement of individuals in the community's organizations, an important element of social capital is the intensity of informal social contacts. The participation of individuals in informal networks is measured by the intensity of bridging ties (with friends, colleagues and people from the immediate environment) and bonding social relations (reliance on close family ties). Informal social ties have the character of a safety net and are suitable for building relationships of mutual trust and reciprocity and for mobilizing informal solidarity. Relations between members of these networks are generally characterized as the bonding ties that strengthen relationships within homogenous groups and provide assistance and support in overcoming the problems of material and immaterial character. Tables 2 and 3 account for the data on how many Serbian citizens rely on personal, informal contacts in solving important problems of life. Based on these data, it can be concluded that individuals who live in the Balkan countries highly value relationships with friends and

Table 2 Informal networks: Support/help when looking for a job

\begin{tabular}{l|cccccc}
\hline & $\begin{array}{c}\text { The Republic of } \\
\text { Serbia }\end{array}$ & FYR Macedonia & Montenegro & Croatia & $\begin{array}{c}\text { Average } \\
\text { Balkans }\end{array}$ & Average EU 27 \\
\hline $\begin{array}{l}\text { A member of the } \\
\text { family / a relative }\end{array}$ & $42 \%$ & $44.9 \%$ & $63.7 \%$ & $34.2 \%$ & $46.2 \%$ & $30.6 \%$ \\
$\begin{array}{l}\text { A friend, a neighbor } \\
\text { or someone else }\end{array}$ & $31.6 \%$ & $27.2 \%$ & $22.5 \%$ & $31.6 \%$ & $28.3 \%$ & $24.6 \%$ \\
$\begin{array}{l}\text { A service provider, } \\
\text { institution }\end{array}$ & $9.2 \%$ & $17.8 \%$ & $5.5 \%$ & $14 \%$ & $11.6 \%$ & $23.1 \%$ \\
Nobody & $17.2 \%$ & $10.1 \%$ & $8.3 \%$ & $20.1 \%$ & $13.9 \%$ & $21.8 \%$ \\
\hline
\end{tabular}

Source: Eurofound, Third European Quality of Life Survey, 2012 
Table 3 Informal networks: Urgent loan

\begin{tabular}{l|cccccc}
\hline & $\begin{array}{c}\text { The Republic of } \\
\text { Serbia }\end{array}$ & $\begin{array}{c}\text { FYR } \\
\text { Macedonia }\end{array}$ & Montenegro & Croatia & $\begin{array}{c}\text { Average } \\
\text { Balkans }\end{array}$ & $\begin{array}{c}\text { Average } \\
\text { EU 27 }\end{array}$ \\
\hline A member of the family / a relative & $63.0 \%$ & $68.5 \%$ & $81.4 \%$ & $70.7 \%$ & $70.9 \%$ & $69.4 \%$ \\
A friend, a neighbor or someone else & $28.4 \%$ & $22.4 \%$ & $15.6 \%$ & $20.0 \%$ & $21.6 \%$ & $11.9 \%$ \\
A service provider, an institution & $2.2 \%$ & $3.9 \%$ & $0.5 \%$ & $3.6 \%$ & $2.6 \%$ & $9.2 \%$ \\
Nobody & $6.4 \%$ & $5.3 \%$ & $2.5 \%$ & $5.7 \%$ & $4.9 \%$ & $9.6 \%$ \\
\hline
\end{tabular}

Source: Eurofound, Third European Quality of Life Survey, 2012

the family and rely on their support during their life in a much larger scale in relation to the EU citizens. Conversely, the EU citizens are more likely to seek help or support from official institutions, whereas in RS, a very small percentage relies on institutional capacities in solving the problem of unemployment, financial and other personal or family-related problems. For example, as many as $73.6 \%$ of citizens of RS rely on the help of their families or friends in finding a job, while only $9.2 \%$ use the services of official institutions.

The empirical data suggest that, in the years of economic and political changes after the transition, the citizens of RS and the countries of the region have turned to the strengthening of informal social ties, seeking safety in social niches made up of close relatives and friends. Thus, the transition process in the Balkan countries has caused the creation of social capital to be directed towards the survival and strengthening of informal networks, i.e. the preserving of the characteristics of the social capital from the socialist period. The persistence of informal networks as the main lever for solving everyday problems has been followed by the slow development of broader formal networks.

\section{Trust as the qualitative aspect of social capital}

Measuring the level of generalized trust is based on the respondents' answers to the question "Would you say that most people can be trusted?", where the respondents chose a number on the scale from 1 („You can't be too careful”) to 10 („Most people can be trusted"). The data on the level of generalized trust in $\mathrm{RS}$, its neighboring countries and the average values for the EU-27 are displayed in Table 4.
The empirical data indicate a low level of general trust in RS - only $2.3 \%$ of the respondents from RS opted for number 10, which indicates the maximum level of trust in people in general. The percentage of the respondents who believe that people can be trusted (the sum of responses 6-10) is twice lower (33.5\%) than the percentage of the respondents $(66.3 \%)$ who expressed distrust (the sum of responses 1-5). Compared with the results of research conducted in the $\mathrm{EU}$, we can see a large gap in the level of trust. Earlier surveys of trust indicated the long-term and chronic nature of this gap, along with the evident tendency of a further decline in trust in transition countries, which contributes to the deepening of differences in the level of trust between developed European countries and countries in transition. The levels of trust in the Balkan countries are relatively uniform, indicating similar conditions for the accumulation of social capital. One of the significant predictors (sig $=0.0037$ ) of the level of trust in RS is the level of income, in the sense that the respondents belonging to lower income quartiles reported a lower level of trust in people in general.

Table 4 The level of generalized trust (on the 1-10 scale)

\begin{tabular}{l|c}
\hline Country & Mean value (1-10) \\
\hline The Republic of Serbia & 4.53 \\
FYR Macedonia & 3.54 \\
Montenegro & 4.86 \\
Croatia & 4.59 \\
\hline Average Balkans & 4.38 \\
Average EU 27 & 5.03 \\
\hline
\end{tabular}

Source: Eurofound, Third European Quality of Life Survey, 2012 
An important parameter of social capital in a country is the degree of trust in the institutions of the system. The indicator of institutional trust is based on the estimate scales of trust (in this case, from 1, indicating the total absence of trust, to 10, indicating complete trust) in different institutions. Table 5 shows the data on average trust in various institutions in RS, the countries in the region and the European countries.

The research into trust in institutions in RS shows an alarmingly low level of citizens' trust, especially in political institutions (the parliament, the government). A somewhat higher level of trust is ascribed to the institutions of the judicial system and the protection system; but, according to this indicator, RS is a country faced with the lowest trust of its citizens, even when compared to the countries in the region. The very institutions that are of major importance for the functioning of economic and political life (the judiciary, the government, the parliament) face the lowest level of trust. High correlation coefficients between the indicators of trust in individual institutions indicate that citizens' distrust is directed towards all, instead of individual, institutions (Table 6).

\section{The shadow economy as an obstacle in the business environment}

Different methods are used to measure the size of the informal economy in modern economies, expressing the shadow economy as a percentage of the GDP. One such method is MIMIC (Multiple Indicators, Multiple Causes), that takes into account multiple causes and multiple effects of the informal economy, and therefore represents the most comprehensive method of measuring, both by the sector (households, companies) and by activities. There are methods that measure the shadow economy on the basis of information on compliance with tax regulations in households (the HTC method), where measurement includes those forms of the informal economy which can be observed on the basis of income and household consumption. According to the aforementioned macroeconomic models, the estimates of the shadow economy in RS are around $30 \%$ of the GDP - 30.1\% according to the MIMIC method and $23.6 \%$ in 2010, according to the HTC method (Krstić, Schneider, Arandarenko, Arsić, Radulović, Ranđelović, Janković, 2013).

Due to differences in coverage, the forms of the shadow economy which are subject to measurement and the assessment methodology of the existing models, their results are often complemented by interviewing representatives of firms in order to observe the phenomenon of the gray economy from their perspective and to assess the prevalence of its forms in the business environment. In this sense, as an indicator of the gray economy in this paper, the business community's perceptions of the unfair competition that comes from the informal sector of the economy will be used, as collected by the survey in 2013 (EBRD, 2015).

Table 5 Trust in institutions (on the 1-10 scale)

\begin{tabular}{l|cccccc}
\hline Country & Government & Parliament & Legal system & The press & $\begin{array}{c}\text { Local } \\
\text { authorities }\end{array}$ & Police \\
\hline The Republic of & 2.95 & 2.88 & 3.08 & 3.56 & 3.29 & 4.33 \\
Serbia & 4.18 & 3.90 & 4.00 & 3.93 & 4.06 & 4.66 \\
FYR Macedonia & 4.00 & 4.08 & 4.17 & 4.67 & 3.85 & 4.53 \\
Montenegro & 3.32 & 2.96 & 3.15 & 3.54 & 3.33 & 4.66 \\
Croatia & 3.61 & 3.46 & 3.60 & 3.93 & 3.63 & 4.55 \\
\hline Average Balkans & 4.05 & 4.05 & 4.76 & 4.47 & 5.30 & 5.91 \\
Average EU 27 & & & & & & \\
\hline
\end{tabular}

Source: Eurofound, Third European Quality of Life Survey, 2012 
Table 6 Correlation coefficients between the indicators of trust in institutions

\begin{tabular}{l|ccccc}
\hline & Parliament & Legal system & The press & Police & Covernment \\
\hline Legal system & $0.766^{* *}$ & - & - & - & - \\
The press & $0.556^{* *}$ & $0.539^{* *}$ & - & - & - \\
Police & $0.584^{* *}$ & $0.590^{* *}$ & $0.572^{* *}$ & - & - \\
Government & $0.806^{* *}$ & $0.721^{* *}$ & $0.604^{* *}$ & $0.627^{* *}$ & - \\
Local authorities & $0.690^{* *}$ & $0.634^{* *}$ & $0.566^{* *}$ & $0.544^{* *}$ & $0.760^{* *}$ \\
\hline
\end{tabular}

Note: $* * p<0.01$

Source: Authors, based on: Eurofound, Third European Quality of Life Survey, 2012

According to the results of this survey, the three most important obstacles in business in RS are political instability, tax rates and access to financial resources (Table 7). However, over $10 \%$ of the firms in the sample highlight the practices of competitors from the informal sector as the key challenge they are faced with in their business doing.

That this problem transcends national and even regional boundaries is indicated by the fact that firms from more than one-third of the countries surveyed highlighted the shadow economy as the main obstacle in their business (only in 9 countries, the shadow economy is not placed among the three most important barriers). Over $40 \%$ of the surveyed firms reported that they were facing unfair competition from the informal sector. The shadow economy in this study does not only cover the activities of the firms that are not formally registered, but also the activities of registered firms, such as reporting lower income, fewer employees or lower wages in order to avoid paying taxes or obtaining necessary documentation. The prevalence of the informal activity is most visible in the businesses whose turnover is mainly made in cash (small shops, taxi services), as well as in the sectors of construction, agriculture and services provided to households (EBRD, 2015).

Different firms in RS have different perceptions of the informal economy - certain types of firms are to a greater extent exposed to competition from the informal sector, such as small firms, young firms and those operating in small towns (Table 8).

The detailed data on the firms' perceptions of the informal economy as an obstacle to their business are shown in Table 9. Only $40.83 \%$ of the firms did not report on problems with the competition from the informal sector, while about $6 \%$ of the firms indicated that it was the most serious obstacle to business. Onethird of the surveyed firms believe that the business of competitors from the informal sector of the economy

Table 7 The most important obstacles in the Serbian business environment

\begin{tabular}{l|cc}
\hline Obstacle & $\begin{array}{c}\text { Number of } \\
\text { firms }\end{array}$ \\
\hline Access to finance & 52 & 14.44 \\
Access to land & 2 & 0.56 \\
Business licenses and permits & 6 & 1.67 \\
Corruption & 22 & 6.11 \\
Courts & 18 & 5.00 \\
Crime, theft and disorder & 12 & 3.33 \\
Customs and trade regulations & 14 & 3.89 \\
Electricity & 3 & 0.83 \\
Inadequately educated workforce & 7 & 1.94 \\
Labor regulations & 6 & 1.67 \\
Political instability & 70 & 19.44 \\
Practices of competitors in the & 39 & 10.83 \\
informal sector & & \\
Tax administration & 17 & 4.72 \\
Tax rates & 60 & 16.67 \\
Transport & 2 & 0.56 \\
n/a & 30 & 18.61 \\
\hline Total & 360 & 100.00 \\
\hline
\end{tabular}

Source: EBRD, BEEPS V Report, 2015a 
Table 8 The characteristics of firms that consider the shadow economy as the major obstacle

\begin{tabular}{|c|c|}
\hline & $\begin{array}{l}\text { Number of } \\
\text { firms }\end{array}$ \\
\hline \multicolumn{2}{|l|}{ Firm size } \\
\hline Mikcro & 2 \\
\hline Small & 22 \\
\hline Medium & 12 \\
\hline \multirow[t]{2}{*}{ Large } & 3 \\
\hline & 39 \\
\hline \multicolumn{2}{|l|}{ Years of operation } \\
\hline Under 5 & 1 \\
\hline $6-25$ & 38 \\
\hline $26-50$ & 0 \\
\hline \multirow[t]{2}{*}{ Over 51} & 0 \\
\hline & 39 \\
\hline \multicolumn{2}{|l|}{ Industry } \\
\hline Manufacturing & 12 \\
\hline Retail & 13 \\
\hline Other services & 14 \\
\hline & 39 \\
\hline \multicolumn{2}{|l|}{ Ownership } \\
\hline Private domestic capital & 33 \\
\hline Private foreign capital & 4 \\
\hline State capital & 0 \\
\hline Others & 2 \\
\hline & 39 \\
\hline \multicolumn{2}{|l|}{ Region } \\
\hline Belgrade & 11 \\
\hline Vojvodina & 11 \\
\hline Sumadija and Western Serbia & 13 \\
\hline South and Eastern Serbia & 4 \\
\hline & 39 \\
\hline \multicolumn{2}{|l|}{ Size of the locality } \\
\hline Over 1 million (capital) & 11 \\
\hline 250000 to million & 2 \\
\hline $50000-250000$ & 10 \\
\hline Less than 50000 & 16 \\
\hline & 39 \\
\hline
\end{tabular}

Source: EBRD, BEEPS V Report, 2015a
Table 9 The perceptions of the shadow economy as an obstacle for business in The Republic of Serbia

\begin{tabular}{l|cc}
\hline $\begin{array}{l}\text { The perceptions of the shadow } \\
\text { economy as an obstacle }\end{array}$ & $\mathrm{N}$ & $\%$ \\
\hline No obstacle & 147 & $40.83 \%$ \\
Minor obstacle & 71 & $19.72 \%$ \\
Moderate obstacle & 55 & $15.28 \%$ \\
Major obstacle & 40 & $11.11 \%$ \\
Very severe obstacle & 21 & $5.83 \%$ \\
Don't know & 5 & $1.39 \%$ \\
No answer & 21 & $5.83 \%$ \\
\hline Total & 360 & $100 \%$ \\
\hline
\end{tabular}

Source: EBRD, BEEPS V Report, 2015a

threatens their work (the sum of the categories moderate, major and very severe obstacle).

The survey found that $45 \%$ of the firms were facing competitors from the informal sector in their business. More than $12 \%$ of the firms pointed out that the number of competitors from the informal sector were too many to count. Only $2.71 \%$ of the firms included in the sample pointed out that there was no competition at all. The average number of competitors from the informal sector reported by the surveyed firms is 16.87 . Table 10 presents the detailed data on the number of competitors from the informal sector of the economy.

Table 10 The number of competitors

\begin{tabular}{l|cc}
\hline The number of competitors & $\mathrm{N}$ & $\%$ \\
\hline No competitors & 9 & $2.71 \%$ \\
$1-5$ & 104 & $31.33 \%$ \\
$6-10$ & 72 & $21.69 \%$ \\
$10-50$ & 69 & $20.78 \%$ \\
$51-99$ & 6 & $1.81 \%$ \\
100 & 13 & $3.92 \%$ \\
Too many to count & 41 & $12.35 \%$ \\
No answer & 18 & $5.42 \%$ \\
\hline Total & 332 & $100 \%$ \\
\hline
\end{tabular}

Source: EBRD, BEEPS V Report, 2015a 


\section{CONCLUSION}

Methodological problems and dilemmas that accompany all attempts at measuring intangible social resources, such as trust, the density of social networks and the prevalence of the informal economy, represent one of the essential limitations to the research into the relation between social capital and the volume of informal transactions. However, up-to-date surveys of these phenomena have reached a satisfactory level of objectivity and precision, so today, they constitute the basis for drawing valid conclusions about relations between different social indicators. The main contribution of this paper relates to extending the analysis of potential causes for the informal economy in RS by pointing to the characteristics of social ties as potential determinants of informal transactions in the economy. Based on the comprehensive surveys used in this paper, the population and the economy of RS can be argued to be facing some serious challenges.

First of all, the data on social relations indicate that the development of social capital in RS in the years of intense economic and political changes during the transition was directed towards the degradation of generalized trust, trust in institutions and participation in formal social networks. Distrust towards people in general and the feeling that they cannot rely on formal institutions affected the citizens of RS to nurture informal social ties and a specific type of trust characteristic of homogeneous, closed groups. The specificities of social capital in RS are reflected in the fact that strong informal networks inherited from the pre-transition period, created as a substitute for functional formal systems under conditions of uncertainty and shortages, persist even today, 15 years after the beginning of the transition.

Strong informal networks and particularized trust are often referred to as negative social capital in social capital theory given the fact that this kind of social connections and relations facilitate the realization of socially undesirable activities - crime, corruption, the shadow economy. The estimates of the shadow economy from the perspective of the firms indicate that the informal sector of the economy is so widespread that it represents a very severe obstacle to doing business in RS. The unfair competition of formally unregistered firms and activities of registered firms aimed at the circumvention or evasion of financial obligations towards the state, impose additional problems to firms in RS, which, according to international standards, is considered to be a low competitive economy.

Taking into account the effect of the institutional factors that affect the development of the shadow economy (the tax burden, the level of the regulation of the economy, the capacity of the state administration), that were not the subject of the analysis carried out in this paper, based on the presented data on social capital and the shadow economy in RS, it can be concluded that, according to the initial assumptions, a high level of particularized trust and a lack of trust in institutions encourage the growth of the shadow economy,

The findings of the paper indicate the need for the further estimation of the shadow economy in RS, as well as for the establishing of clear quantitative relationships between the individual elements of social capital and the distribution of the shadow economy. In order to discover the key causes and factors that increase the intensity of informal transactions, it is necessary that the shadow economy should be analyzed within the context of the comprehensive models that will determine the specific importance of both the institutional factors and the social determinants of the shadow economy.

\section{ACKNOWLEDGEMENTS}

This paper is a part of the research Project (No. 179066), which is funded by the Ministry of Education, Science and Technological Development of the Republic of Serbia.

\section{REFERENCES}

Burroni, L., Crouch, C., Kaminska, M., \& Valzania, A. (2008). Local Economic Governance in Hard Times: The Shadow Economy and the Textile and Clothing Industries around Łodz and Naples. Socio-Economic Review, 6(2), 473-492. doi: 10.1093/ser/mwn005

Busse, S. (2001). Strategies of Daily Life: Social Capital and the 
Informal Economy in Russia. Sociological Imagination, 38(3), 166-189.

Castells, M. (1997). The power of identity. MA, USA and Oxford, UK: John Wiley \& Sons, Ltd., Publication.

Coleman, J. (1990). Foundations of Social Theory. Cambridge, MA, USA: The Belknap Press of Harvard University Press.

Dasgupta, P. (2000). Economic progress and the idea of social capital. In P. Dasgupta and I. Serageldin (Eds.). Social capital: A multifaceted perspective (pp. 325-424). Washington D.C. USA: World Bank.

De Soto, H. (2000). The Mystery of Capital: Why Capitalism Triumphs in the West and Fails Everywhere Else. New York, NY: Basic Books.

Eurofound. (2012). Third European Quality of Life Survey, 20112012. [computer file]. 2nd Edition. Colchester, Essex: UK Data Archive [distributor]. Retrieved January 2014, SN: 7316, from http://dx.doi.org/10.5255/UKDA-SN-7316-2

European Bank for Reconstruction and Development (EBRD). (2015). Business Environment and Enterprise Performance Survey. Retrieved August 31, 2015, from http://ebrd-beeps. com/data/

European Bank for Reconstruction and Development (EBRD). (2015a). The Business Environment in the Transition Region. BEEPS V Report. Retrieved September 4, 2015 http://ebrdbeeps.com/reports/beeps_v_report/

Field, J. (2003). Social Capital. London, UK and New York, NY: Routledge.

Flap, H., \& Volker, B. (2003). Communist Societies, the Velvet Revolution, and Weak Ties: The Case of East Germany. In G. Badescu, and E. Uslaner, (Eds.). Social Capital and the Transition to Democracy. London, UK: Routledge.

Fukuyama, F. (1995). Trust: The Social Virtues and the Creation of Prosperity. London, UK: Hamish Hamilton.

Fukuyama, F. (2000). Social Capital and Civil Society. Working Paper 00/74, Washington D.C. USA: International Monetary Fund.

Grossman, G. (1989). Informal Personal Incomes and Outlays of the Soviet Urban Population, In A. Portes, M. Castells, \& L. Benton (Eds.), The Informal Economy: Studies in Advanced and Less Developed Countries (pp. 150-170). Baltimore, MD: Johns Hopkins University Press.

Johnson, S., Kaufmann, D., \& Zoido-Lobatón, P. (1998). Regulatory Discretion and the Unofficial Economy. American Economic Review, 88(2), 387-392.

Kloosterman, R., van der Leun, J. \& Rath, J. (1999). Mixed embeddedness: (In)formal Economic and Immigrant Business in the Netherlands. International Journal of Urban and Regional Research, 23(2), 252-266.

Krstić, G., Schneider, F., Arandarenko, M., Arsić, M., Radulović, B., Ranđelović, S. i Janković, I. (2013). Siva ekonomija u Srbiji: Novi nalazi i preporuke za reforme. Beograd, Republika Srbija: Fondacija za razvoj ekonomske nauke.

Ledeneva, A. (1998). Russia's Economy of Favours: Blat, Networking, and Informal Exchanges. New York, NY: Cambridge University Press.

Lekovic, V. (2012). Trust as an institutional factor of economic success. Economic Horizons, 14(2), 65-78. doi: 10.5937/ ekonhor1202063L

Levy, S. (2008). Good Intentions, Bad Outcomes: Social Policy, Informality, and Economic Growth in Mexico. Washington D.C. USA: Brookings Institution Press.

McKinsey (2004). The Hidden Dangers of the Informal Economy. McKinsey Quarterly, 3, 27-37. http://immagic.com/ eLibrary/ARCHIVES/GENERAL/MCKNSYUS/M040413F. pdf

Millar, J. (Ed.). (1987). Politics, Work and Daily Life in the USSR: A survey of former Soviet citizens. Cambridge, USA: Cambridge University Press.

Portes, A. (1994). The Informal Economy and its Paradoxes. In N. Smelser, \& R. Swedberg (Eds.), The Handbook of Economic Sociology (pp. 426-449). Princeton, USA: Princeton University Press.

Portes, A. (Ed.). (1995). The Economic Sociology of Immigration: Essays on Networks, Ethnicity and Entrepreneurship. New York City, NY: Russell Sage.

Portes, A. (1998). Social Capital: Its Origins and Applications in Modern Sociology. Annual Review of Sociology, 24(1), 1-24.

Portes, A. (2010). Economic Sociology: A Systematic Inquiry. Princeton, USA: Princeton University Press.

Portes, A., \& Landolt, P. (1996). The downside of social capital. The American Prospect, 7(26), 18-21.

Schneider, F., Buehn, A., \& Montenegro, C. E. (2010). Shadow Economies All over the World. New Estimates for 162 Countries from 1999 to 2007. Washington D.C. USA: World Bank.

Thomas, J. (1992). Informal Economic Activity. New York, NY: Harvester.

Van Deth, J. (2003). Measuring Social Capital: Orthodoxies and Continuing Controversies. International Journal of Social Research Methodology, 6(1), 79-92. DOI: $10.1080 / 13645570210156040$ 


\section{Received on $10^{\text {th }}$ November 2015 \\ after revision, \\ accepted for publication on $15^{\text {th }}$ December 2015. \\ Published online on $25^{\text {th }}$ December 2015.}

Natasa Golubovic is a Professor at the Faculty of Economics, University of Nis. She defended her doctoral dissertation, at the Faculty of Economics, University of Belgrade, the Republic of Serbia. She teaches: Introduction to Economics, Political Economy, Social Economics, and Public Choice Economics. The scientific research fields of her interest are economic policy analysis and institutional analysis. She is an author of several text books, monographs and articles published in national and international journals. She participated in several conferences of national and international importance.

Marija Dzunic is an Associate Professor at the Faculty of Economics, University of Nis, Department for General Economic Theory. She obtained her PhD in Economics, at the Faculty of Economics, University of Belgrade, the Republic of Serbia. She teaches: Introduction to Economics, Political Economy, Social Economics, and Economics of Public Choice. Her research is focused on social capital and economic growth. She is the author of numerous articles published in national and international journals, and has participated in several international and national conferences. 


\title{
DRUŠTVENI KAPITAL KAO DETERMINANTA SIVE EKONOMIJE U REPUBLICI SRBIJI
}

\author{
Nataša Golubović* i Marija Džunić \\ Ekonomski fakultet Univerziteta u Nišu
}

\begin{abstract}
Koncipiranje i primena mera usmerenih na uvođenje sive ekonomije $u$ legalne tokove pretpostavljaju poznavanje uzroka i strukture neformalne aktivnosti. Uticaj institucionalnih faktora koji podstiču razvoj sive ekonomije (poreskog opterećenja, stepena regulacije privrede, kapaciteta državne uprave), predmet je brojnih teorijskih i empirijskih istraživanja. Za razliku od toga, uticaj društvenog kapitala, odnosno, karaktera društvenih veza i odnosa na sivu ekonomiju, istraživan je u manjoj meri. Polazeći od toga da je u Republici Srbiji (RS) neformalni sektor privrede rasprostranjen toliko da predstavlja važnu prepreku poslovanju preduzeća u RS, cilj ovog rada je da istraži da li karakteristike društvenih veza i odnosa, odnosno, društvenog kapitala u RS, predstavljaju pogodno tle za rast sive ekonomije. U tom kontekstu, posebno će se analizirati karakteristike i učestalost društvenih kontakata, partikularizovano poverenje i institucionalno poverenje, kao determinante sive ekonomije u Republici Srbiji.
\end{abstract}

Ključne reči: društveni kapital, društvene mreže, poverenje, siva ekonomija

JEL Classification: E26, O17, Z136

\section{UVOD}

Siva ekonomija predmet je istraživanja različitih nauka, počev od ekonomije, antropologije, političkih nauka, sociologije. Ključna pitanja u istraživanju ovog fenomena u ekonomskoj nauci odnose se na veličinu i strukturu sive ekonomije, uzroke rasta sive ekonomije, njene posledice na produktivnost i blagostanje, uticaj na privredni rast, siromaštvo i nejednakost. Iako siva ekonomija obezbeđuje egzistenciju milionima ljudi i predstavlja svojevrsnu „sigurnosnu mrežu” za mnoge

\footnotetext{
* Korespondencija: N. Golubović, Ekonomski fakultet Univerziteta u Nišu, Trg Kralja Aleksandra 11, 18000 Niš, Republika Srbija; e-mail: natasa.golubovic@eknfak.ni.ac.rs
}

pojedince i porodice, negativni efekti po privredu i društvo daleko prevazilaze njene pozitivne efekte.

Mere usmerene na uvođenje sive ekonomije $u$ legalne tokove zasnivaju se na poznavanju uzroka i strukture neformalnih aktivnosti. U tom pogledu, poseban problem predstavlja činjenica da su podaci o neformalnim aktivnostima nepouzdani i nepotpuni. Siva ekonomija predstavlja složenu celinu, sastavljenu od čitavog niza različitih aktivnosti, zbog čega njeno merenje predstavlja poseban izazov.

Budući da se neformalne transakcije oslanjaju na društvene veze, istraživanje načina na koji društvene mreže funkcionišu važno je za potpunije razumevanje sive ekonomije. Društveni kapital bivših socijalističkih 
privreda karakteriše obilje društvenih veza koje su građene sa ciljem prevazilaženja nestašica dobara i usluga. Te veze sada se koriste, zajedno sa drugim resursima, $u$ svrhu rešavanja problema u tržišnoj ekonomiji. Neformalne ekonomske transakcije nastavile su da igraju važnu ulogu i u periodu tranzicije, popunjavajući prazninu nastalu kao rezultat urušavanja postojećih institucija socijalističke privrede i spore izgradnje institucija tržišne privrede (Busse, 2001).

Cilj ovog rada je da istraži da li karakteristike društvenih veza i odnosa, odnosno, društvenog kapitala u Republici Srbiji (RS) predstavljaju pogodno tle za rast sive ekonomije. Pretpostavke od kojih polazimo $\mathrm{u}$ analizi su da učestalost društvenih kontakata i međusobno (partikularizovano) poverenje podstiču rast sive ekonomije, dok institucionalno poverenje negativno utiče na njen rast. Ispitivanje nivoa raspoloživog društvenog kapitala, u smislu inteziteta društvenih kontakata, gustine društvenih mreža i postojećeg nivoa međusobnog i institucionalnog poverenja, biće zasnovano na podacima Tréceg ispitivanja kvaliteta života u Evropi (Third European Quality of Life Survey, Eurofound, 2012), dok će se kao mera sive ekonomije koristiti podaci o percepcijama predstavnika poslovne zajednice koje se odnose na rasprostranjenost sive ekonomije u RS, koji su rezultat petog talasa Istraživanja o poslovnom okruženju i učinku preduzeća (Business Environment and Enterprise Performance Survey - BEEPS V), koje sprovodi Evropska banka za obnovu i razvoj (EBRD, 2015). Polazeći od postojećih istraživanja o uticaju društvenog kapitala na sivu ekonomiju, analiza empirijskih podataka o nivou društvenog kapitala obuhvatiće kako kvantitativni aspekt društvenih odnosa, $\mathrm{u}$ vidu intenziteta neformalnih društvenih kontakata $u$ okviru društvenih mreža, tako i kvalitativne aspekte društvenog kapitala, u smislu nivoa specifičnih tipova poverenja, relevantnih za podsticanje ili ograničavanje neformalnih ekonomskih transakcija. Na kraju rada biće sistematizovani osnovni zaključci do kojih se istraživanjem došlo.

\section{PREGLED LITERATURE}

$\mathrm{Ne}$ postoji jedinstvena definicija, niti indikator sive ekonomije. Siva ekonomija najčešće se definiše kao skup ekonomskih aktivnosti koje se obavljaju van institucionalizovanog privrednog ambijenta. Ukoliko se formalna ekonomija posmatra kao skup svih registrovanih ekonomskih transakcija, onda siva ekonomija obuhvata sve ekonomske transakcije koje nisu registrovane, odvijaju se bez odgovarajućih dozvola, nisu oporezovane i nisu regulisane (Thomas, 1992; Portes, 1995). Naziva se još i privredom u senci, neformalnim sektorom, neregularnim sektorom, crnim tržištem itd. Privredna aktivnost opisana ovim pojmovima neregularna je u smislu da pojedinci koje se njome bave, kako kupci tako i prodavci, nastoje da tu aktivnost sakriju od države. Oni to čine kako bi izbegli obavezu pribavljanja dozvola potrebnih za bavljenje tom delatnošću, izbegli propise i plaćanje poreza.

U zemljama u razvoju, u sivoj ekonomiji odvija se preko polovine ekonomske aktivnosti. Ona obezbeđuju egzistenciju milionima ljudi. Ipak, njena uloga $u$ ekonomskom razvoju ostaje kontroverzna. Neki autori, poput H. de Soto-a (2000), u preduzećima koja posluju u sivoj ekonomiji vide neiskorišćeni rezervoar preduzetničke energije, koji je suzbijen državnom regulacijom. U tom pogledu, olakšavanje pristupa tržištu i bolje definisanje i zaštitita svojinskih prava oslobodilo bi tu energiju, koja bi podsticajno delovala na privredni rast i razvoj. Drugi, poput S. Levy-a (2008), ukazuju na tamniju stranu sive ekonomije, a to su prednosti koje ova preduzeća uživaju u pogledu izbegavanja poreza i propisa. U Izveštaju Globalnog instituta McKinsey (2004), preduzeća u sivoj ekonomiji opisuju se kao paraziti koji nelojalno konkurišu preduzećima u regularnoj ekonomiji, koja posluju u skladu sa važećom zakonskom regulativom.

Siva ekonomija negativno utiče na ekonomsku efikasnost. Prvo, povećavaju se transakcioni troškovi, jer kupci moraju da posvete više vremena obavljanju transakcije, pređu veću udaljenost da bi obavili razmenu i sl. Takođe, $\mathrm{u}$ procesu razmene kupci često dobijaju robu lošijeg kvaliteta, kao i robu bez garancije (koja ide uz robu proizvedenu u legalnoj ekonomiji). Prelaskom u sivu ekonomiju preduzeća su u poziciji da zaobilaze sigurnosne i ekološke standarde, što znači da se zbog većih rizika kojima su potrošači i zaposleni izloženi, kao i zbog negativnih eksternih efekata na okolinu, smanjuje nivo društvenog blagostanja. Radnicima koji rade u sivoj ekonomiji ne uplaćuje se 
socijalna i zdravstvena zaštita, što ima šire posledice s aspekta nejednakosti i siromaštva. Dalje, država gubi prihod od poreza i dozvola, koje je mogla da prikupi. Taj gubitak može da primora državu da poveća poreske stope ili uvede dodatne poreze kojima bi pokrila svoje izdatke, što dovodi do novih distorzija i novog prelaska aktivnosti u sivu ekonomiju. Ovo je posebno važno za zemlje koje se suočavaju sa izazovom fiskalne konsolidacije, poput RS. Treba dodati i to da svi oni koji učestvuju u sivoj ekonomiji krše neki zakon ili propis, a verovatno i neke običaje lokalne zajednice. Svako ko prekrši neki zakon i prođe nekažnjeno, može doći u iskušenje da krši i druge zakone. Na ovaj način podriva se moralna struktura zajednice.

Istraživanja uzroka sive ekonomije uglavnom su koncentrisana na dve grupe faktora:

- institucionalne faktore, $\mathrm{i}$

- odnose između pojedinaca, kao i odnose između pojedinaca i države.

Prva grupa faktora odnosi se na institucionalne uslove koji omogućavaju razvoj sive ekonomije. U okviru ove grupe faktora, analizira se uticaj stepena regulacije privrede, poreskog tereta i kapaciteta državne uprave. Kada odlučuje hoće li preći u sivu ekonomiju ili ne, racionalni akter upoređuje koristi od poslovanja u sivoj ekonomiji i potencijalni trošak u vidu odgovarajuće kazne koju će platiti ukoliko bude uhvaćen. Porezi i drugi oblici državne regulacije mogu da smanje ekonomsku efikasnost i društveno blagostanje time što deformišu izbor između dobara, između rada i dokolice itd. Oni utiču i na izbor između obavljanja delatnosti u regularnoj ekonomiji i sivoj ekonomiji. Relativno veliki neformalni sektor mogao bi se objasniti velikim troškovima regulacije i oporezivanja koje snose pojedinci i preduzeća, zbog kojih imaju koristi ako pređu u sivu ekonomiju, a male kazne ako budu uhvaćeni. Ove zaključke potvrđuju rezultati analize S. Johnson-a, D. Kaufmann-a i P. Zoido-Lobaton-a (Johnson, Kaufmann \& Zoido-Lobaton, 1998), koji su na uzorku od 49 zemalja (Latinske Amerike, Bivšeg SSSR-a i OECD-a) ustanovili da je siva ekonomija veća što je veći stepen regulacije u privredi, veći poreski teret, slabija vladavina prava, veći stepen korupcije u državnoj birokratiji. Prva dva skupa varijabli obično mere koristi od prelaska u sivu ekonomiju, $u$ cilju izbegavanja uplitanja države i oporezivanja, a druga dva povezana su sa verovatnoćom otkrivanja i kažnjavanja. Što je vladavina prava slabija i što su državni činovnici korumpiraniji, to je verovatnije da se zakon može zaobići, ili činovnik podmititi kako bi se izbegla kazna.

Druga grupa faktora odnosi se na društvene odnose, odnosno, istraživanje uticaja društvenog kapitala, pre svega, društvenih mreža, međusobnog poverenja i poverenja $u$ institucije. Društveni kapital igra važnu ulogu u obavljanju transakcija u sivoj ekonomiji. Što se više siva ekonomija približava modelu pravog tržišta, to je više zavisna od društvenih veza $u$ svom funkcionisanju (Portes, 1994, 430). Znatan deo ekonomskih transakcija u sivoj ekonomiji pretpostavlja postojanje društvenih veza, odnosno, neke vrste društvenog kapitala. Pojava i rast sive ekonomije, ne može se objasniti samo ekonomskim pritiscima (Burroni, Crouch, Kaminska \& Valzania, 2008, 487). Važnu ulogu igra i slabost javnih institucija, visok nivo organizovanog kriminala, specifičnosti institucionalnog okvira, kvalitet mehanizama za implementaciju, nizak nivo institucionanog poverenja i visok nivo partikularizovanog (međusobnog) poverenja. A. Portes (1998), takođe, ukazuje na to da postoji skup faktora koji podstiče neformalne aktivnosti, a odnosi se na kvantitet i kvalitet društvenih odnosa. Kvantitativni aspekt društvenih odnosa najbliži je klasičnom pristupu društvenom kapitalu, gde se na društvene veze gleda kao na svojevrstan resurs. U osnovi koncepta društvenog kapitala jesu društveni odnosi; bolje rečeno, karakteristike društvenih odnosa koje omogućavaju ekonomskim akterima da ostvare svoje ciljeve. A. Portes (1998, 6), kao srž koncepta društvenog kapitala, ističe sposobnost aktera da obezbedi koristi na osnovu članstva u društvenim mrežama ili drugim društvenim strukturama. U tom smislu, društveni kapital podrazumeva ukupnost aktuelnih i potencijalnih resursa koje određena društvena grupa može da mobiliše kroz svoje članove. Društveni kapital se, međutim, razlikuje od ostalih oblika kapitala, jer je sastavni deo društvenih odnosa, a ne samih aktera (Coleman, 1990).

Iako se o društvenim mrežama piše uglavnom $\mathrm{u}$ afirmativnom kontekstu, one mogu da produkuju 
i negativne posledice (Portes \& Landolt, 1996). Po P. Dasgupta-u (2000, 390), društvene mreže mogu predstavljati podsticaj, ili prepreku, u zavisnosti od razloga zbog kojeg su nastale. Ukoliko pojedinac ima gustu mrežu odnosa sa drugim pojedincima, rastu šanse da se poveže sa onim akterima koji su u stanju da realizuju neformalne transakcije. Drugim rečima, broj i učestalost društvenih konatakata ohrabruje uključivanje $\mathrm{u}$ neformalne aktivnosti. Pretpostavka da je gustina društvenih veza proporcionalna broju neformalnih transakcija zasniva se na višim opštim transakcionim troškovima neformale razmene. Troškovi prikupljanja informacija u cilju obavljanja neformalnih transakcija veći su zato što, $\mathrm{u}$ odsustvu komunikacije putem medija i reklame, učesnici u neformalnim trasakcijama zavise od prijatelja, rođaka i poznanika. J. Field $(2003,83)$ ističe da treba praviti razliku između produktivnih društvenih mreža koje imaju pozitivne efekte za članove i društvenu zajednicu u celini, i društvenih mreža koje imaju pozitivne efekte za članove, ali negativne za širu zajednicu. Istražujući društvene mreže u Holandiji, R. Kloosterman, J. van der Leaun i J. Rath (1999) ukazali su na to da mnogi imigranti koji dođu u Holandiju, $\mathrm{u}$ nedostatku finansijskih resursa i odgovarajućeg obrazovanja i kvalifikacija, nemaju mnogo opcija na raspolaganju. Kako bi preživeli na konkurentnim tržištima, okreću se neformalnim ekonomskim aktivnostima, koje zavise od specifičnih društvenih mreža - uglavnom zasnovanih na etničkim vezama. U ovom slučaju, gde su neformalne aktivnosti direktna posledica ograničenih mogućnosti na formalnom tržištu rada, društveni kapital igra važnu ulogu.

U periodu centralno-planskog upravljanja tržištem, transakcije na crnom tržištu predstavljale su mehanizam za prevazilaženje problema $u$ vezi sa nestašicom roba i usluga u regularnoj ekonomiji (Millar, 1987; Grossman, 1989). Oskudica i prisustvo korupcije primorali su građane da koriste neformalne veze za ostvarivanja svakodnevnih transakcija, poput nabavke proizvoda, medicinske nege, dobijanja kredita i sl. Neformalne mreže koje su se tada razvile bile su od suštinske važnosti za svakodnevni život. U periodu socijalizma, pojedinci su gradili mreže sa krugom ljudi kojima su mogli verovati. Reč je o malim mrežama koje su im omogućavale da se izbore sa poteškoćama u svakodnevnom životu, da dođu do retkih dobara, pomognu bliskim prijateljima, rođacima i susedima (Ledeneva, 1998). Pomenute mreže, koje su igrale važnu ulogu $u$ bivšim socijalističkim privredama, predstavljale su zamenu za šire društvene mreže koje nisu mogle da egzistiraju u represivnim režimima (Ledeneva, 1998; Flap \& Voelker, 2003).

Neformalne ekonomske transakcije nastavile su da igraju važnu ulogu u svakodnevnom životu i u periodu tranzicije. I pored razvoja formalnih institucija, formalne i neformalne ekonomske transakcije i dalje koegzistiraju u ovim zemljama. Kao jedan od primera možemo da navedemo iznajmljivanje stanova, koje može da se odvija preko agencija, ali i neformalnim kanalima. Ili, trgovina devizama „na crno", mimo banaka i ovlašćenih menjačnica. Čak i kada postoje formalne institucije, pojedinci se i dalje oslanjaju na neformalne aranžmane, jer je to za njih lakše, jeftinije, profitabilnije (makar u kratkom roku), i ima manje prepreka za ulazak.

Pored broja društvenih kontakata, i kvalitativna dimenzija društvenih odnosa, takođe, igra važnu ulogu u neformalnoj razmeni. Kvalitativna dimenzija društvenog kapitala odnosi se na poverenje i često se označava kao kulturna dimenzija društvenog kapitala (Van Deth, 2003). Poverenje ima sličnu ulogu kao i društvene veze - smanjuje transakcione troškove. Ova uloga je čak izraženija u slučaju neformalnih transakcija u odnosu na formalne zato što su pojedinci, $\mathrm{u}$ nedostatku formalnih mehanizama sprovođenja ugovora (policija, sudovi), upućeni na međusobno poverenje. Međusobno poverenje služi i kao garancija da učesnici u neformalnoj transakciji neće prijaviti jedni druge policiji. A. Portes (2010) navodi primer tesnih veza u jevrejskoj zajednici u Gruziji, u vreme bivšeg SSSR-a. Mnogi od njih bili su uspešni preduzetnici u sivoj ekonomiji, zaobilazeći centralizovanu privredu. To je bilo moguće zahvaljujući jakom međusobnom poverenju, utkanom $u$ čvrste mreže bazirane na zajedničkom poreklu i kulturi.

Ovde treba ukazati na razliku između generalizovanog poverenja i međusobnog poverenja. Generalizovano poverenje predstavlja ex ante spremnost da se sarađuje, odnosno, obavljaju transakcije sa anonimnom drugom stranom. Međusobno poverenje odnosi se na poverenje 
unutar grupa međusobno povezanih pojedinaca, baziranih na profesiji, polu, političkim ili religioznim ubeđenjima, rasnoj ili nacionalnoj pripadnosti itd. Društvene grupe mogu da kreiraju visok nivo interne solidarnosti i poverenja. Međutim, mnoge grupe postižu internu koheziju na štetu drugih, koji se tretiraju sa sumnjom i nepoverenjem, što produkuje značajne negativne eksterne efekte za društvo $u$ kome funkcionišu (Fukuyama, 2000). U ovom slučaju, visok nivo poverenja unutar grupe, koincidira sa slabljenjem poverenja prema ostalim pojedincima $u$ društvu. Ekonomske prednosti društvenih mreža bivaju potkopane nemogućnošću uspostavljanja tzv. premošćujućih veza između društvenih grupa, što dovodi do formiranja zatvorenih, parohijalnih mreža (Fukujama, 1995; Castells, 1997). Pored parohijalizma, drugi razlog za zabrinutost odnosi se na sklonost mreža da podstiču tajnost i prikrivanje, što podriva poštovanje zakona i poretka. Tako, umesto da podstiču ekonomsku efikasnost, postojeće društvene mreže u stvari podstiču korupciju i oportunističko ponašanje.

Pored poverenja između pojedinaca, važno je i poverenje pojedinaca $\mathrm{u}$ institucije. $\mathrm{U}$ uslovima niskog nivoa poverenja $\mathrm{u}$ institucije, pritisak na državne službenike da kvalitetnije i odgovornije obavljaju svoje dužnosti je slab. Sa rastom nivoa poverenja jača javni pritisak na državne službenike, stvaraju se pretpostavke za efikasnije javno upravljanje i stvaranje poslovnog ambijenta koji je podsticajan za ekonomske aktivnosti (Lekovic, 2012, 65-78). Postoji inverzan odnos između institucionalnog poverenja i neformalnih transakcija. Ukoliko većina građana u društvu postojeće institucije percipira kao pravične i nepristrasne, onda $u$ takvom društvu postoji poverenje $u$ formalne institucije koje regulišu transakcije. Visok nivo poverenja $u$ institucije odvraća pojedince od učestvovanja u neformalnim transakcijama. S druge strane, ukoliko se državna regulacija doživljava kao mešanje države u oblasti u kojima ne bi trebalo da interveniše, dolazi do erozije poverenja u državne institucije, koje postepeno gube legitimitet. U takvim uslovima, akteri su spremniji da učestvuju u neformalnim aktivnostima. Percipirani kvalitet $i$ legitimnost intervenisanja države u privredu utiče na sklonost aktera da participiraju u neformalnim aktivnostima. Vidimo da poverenje može da ima dvojaki uticaj na neformalni sektor. Pretpostavka je da visok nivo međusobnog poverenja utiče na rast sive ekonomije, dok viši nivo institucionalnog poverenja ima negativan efekat na veličinu neformalnog sektora.

\section{METODOLOŠKI OKVIR I IZVORI PODATAKA}

U cilju ispitivanja potencijalnih uticaja društvenih veza i odnosa na odvijanje neformalnih ekonomskih transakcija u RS, u radu će se koristiti empirijski podaci iz dva istraživanja. Ispitivanje nivoa raspoloživog društvenog kapitala, u smislu inteziteta društvenih kontakata, gustine društvenih mreža i postojećeg nivoa međusobnog i institucionalnog poverenja, biće zasnovano na podacima Tré́eg Ispitivanja kvaliteta života u Evropi (Third European Quality of life Survey, Eurofound, 2012), sprovedenog u svim tadašnjim zemljama članicama EU, kao i u sedam od devet zemalja koje su u tom trenutku bile uključene u proces proširenja (Hrvatska, BJR Makedonija, Island, Kosovo, Crna Gora, Republika Srbija i Turska). Ispitivanje kvaliteta života u Evropi je reprezentativno istraživanje koje sprovodi Evropska fondacija za unapređenje uslova života i rada, a koje predstavlja bogat izvor informacija o uslovima života, smeštaju, lokalnoj životnoj sredini, zdravlju, javnim službama, socijalnoj koheziji i kvalitetu društva, kao i o subjektivnom blagostanju. Za potrebe ovog rada, analiziraće se podaci koji se odnose na poduzorak od 1002 domaćinstva u RS, prikupljeni tokom 2012. godine. U funkciji poređenja stanja društvenog kapitala u RS sa zemljama iz neposrednog okruženja i zemljama EU, biće prikazani i podaci o pojedinačnim elementima društvenog kapitala $u$ Hrvatskoj, Crnoj Gori i BJR Makedoniji, kao i prosečne vrednosti za 27 zemalja EU.

S obzirom na to da je merenje sive ekonomije praćeno objektivnim metodološkim problemima, u naučnim istraživanjima ne postoji univerzalno prihvaćen metod merenja sive ekonomije koji bi ponudio apsolutno pouzdane i potpune podatke. $\mathrm{U}$ tom smislu, razvijeno je mnoštvo različitih modela procene obima sive ekonomije (Krstić, Schneider, Arandarenko, Arsić, Radulović, Ranđelović i Janković, 2013). Najčešće se procene obavljaju na makroekonomskom nivou, a podrazumevaju procenu udela sive ekonomije $\mathrm{u}$ bruto 
domaćem proizvodu (Schneider, Buehn, \& Montenegro, 2010). Međutim, zbog karaktera neformalnih aktivnosti koje podrazumevaju tajne, skrivene i implicitne transakcije, kao potencijalno značajan izvor podataka nameću se percepcije ekonomskih aktera o intezitetu transakcija u okviru sive ekonomije. Merenje društvenih pojava na osnovu podataka o subjektivnim percepcijama ispitanika, takođe, je opterećeno brojnim nedoumicama, pre svega, zbog odsustva vrednosne neutralnosti i objektivnosti ispitanika, što dovodi u pitanje preciznost prikupljenih podataka. Uprkos tome, za čitav niz savremenih društvenih pojava, poput korupcije, sive ekonomije, poverenja, kvaliteta državnih institucija i $\mathrm{sl}$, istraživanje subjektivnih percepcija pojedinaca predstavlja uobičajeni i opšte prihvaćeni način merenja. U tom smislu, $u$ ovom radu će se kao mera sive ekonomije koristiti podaci o percepcijama predstavnika poslovne zajednice koje se odnose na rasprostranjenost sive ekonomije u RS. Ovi podaci su rezultat petog talasa Istraživanja o poslovnom okruženju i učinku preduzeća (Business Environment and Enterprise Performance Survey BEEPS V), koje sprovodi Evropska banka za obnovu i razvoj (EBRD, 2015). Navedeno istraživanje se sprovodi periodično, od 1999. godine, a zasniva se na intervjuima sa rukovodiocima preduzeća u cilju ocene kvaliteta poslovnog okruženja i glavnih izazova u razvoju privatnog sektora. Peti talas istraživanja obavljen je na uzorku od 15883 preduzeća u 30 zemalja Istočne Evrope i Centralne Azije, a za potrebe ovog rada koristiće se rezultati ispitivanja 360 preduzeća u RS, prikupljeni u periodu od januara do avgusta 2013. godine. Vlasnička struktura analiziranih preduzeća uključuje 317 preduzeća u 100\% vlasništvu domaćeg privatnog kapitala, 25 preduzeća u 100\% vlasništvu inostranog kapitala, 10 preduzeća sa određenim procentom $(1 \%$ - 93\%) državnog kapitala i 8 preduzeća u mešovitom vlasništvu. $U$ istraživanje su uključeni svi tipovi preduzeća - mikro, mala, srednja i velika.

Analiza empirijskih podataka o nivou društvenog kapitala obuhvatiće kvantitativni aspekt društvenih odnosa, u vidu intenziteta neformalnih društvenih kontakata u okviru društvenih mreža, i kvalitativne aspekte društvenog kapitala, u smislu nivoa specifičnih tipova poverenja, relevantnih za podsticanje ili ograničavanje neformalnih ekonomskih transakcija.
Ispitivanje nivoa sive ekonomije $\mathrm{u}$ RS biće zasnovano na analizi percepcija predstavnika poslovne zajednice o nelojalnoj konkurenciji iz neformalnog sektora i sivoj ekonomiji kao jednoj od ključnih prepreka poslovanju.

\section{DRUŠTVENI KAPITAL I SIVA EKONOMIJA - EMPIRIJSKI PODACI}

\section{Društveni kapital u okviru društvenih mreža}

Uključenost pojedinaca $\mathrm{u}$ formalne i neformalne društvene mreže predstavlja osnovni pokazatelj mrežne dimenzije društvenog kapitala. Merenje stepena uključenosti $u$ formalne mreže (različite društvene organizacije) zasniva se na pitanjima o pripadnosti različitim dobrovoljnim udruženjima i aktivnom učešću u njihovim aktivnostima. U Tabeli 1 prikazana je učestalost društvenih kontakata građana u vidu aktivnosti u okviru različitih klubova, društava i udruženja. Participacija u ovoj vrsti društvenih mreža omogućava pristup informacijama, otkrivanje novih mogućnosti i napredovanje u društvu. $\mathrm{Na}$ osnovu podataka o participaciji u okviru formalnih mreža, može se zaključiti da preko $70 \%$ građana RS nikad ne ostvaruje ovakav tip društvenih kontakata. Posmatrajući različite kategorije učestalosti, uočljivo je da se participacija $u$ formalnim mrežama nalazi u okvirima specifičnim za zemlje regiona, ali da značajno zaostaje za zemljama EU. Prosečna vrednost indikatora učestalosti jasno potvrđuje činjenicu da je intezitet društvenih kontakata građana RS u okviru formalnih mreža nizak.

Pored angažovanja pojedinaca $u$ društvenim organizacijama, važan element društvenog kapitala je i intezitet neformalnih društvenih kontakata. Za ispitivanje participacije pojedinaca $u$ neformalnim mrežama meri se intezitet premošćujućih veza (sa prijateljima, kolegama i ljudima iz neposrednog okruženja) i učvršćujućih društvenih odnosa (oslanjanje na bliske porodične veze). Neformalne društvene veze imaju karakter zaštitne mreže i pogoduju jačanju odnosa međusobnog poverenja i reciprociteta i mobilisanju neformalne solidarnosti. Odnosi između članova ovih mreža uglavnom se 
Tabela 1 Društvene veze u okviru formalnih mreža (Učestvovanje u aktivnostima kluba, društva ili udruženja)

\begin{tabular}{l|cccccc}
\hline & Republika Srbija & BJR Makedonija & Crna Gora & Hrvatska & Prosek Balkan & Prosek EU 27 \\
\hline $\begin{array}{l}\text { 1 Svakog ili skoro } \\
\text { svakog dana }\end{array}$ & $3,0 \%$ & $1,4 \%$ & $1,9 \%$ & $4,1 \%$ & $2,8 \%$ & $2,5 \%$ \\
$\begin{array}{l}2 \text { Bar jednom } \\
\text { nedeljno }\end{array}$ & $5,7 \%$ & $4,4 \%$ & $4,7 \%$ & $9,7 \%$ & $6,2 \%$ & $12,3 \%$ \\
$\begin{array}{l}3 \text { Jedan do tri puta } \\
\text { mesečno }\end{array}$ & $6,0 \%$ & $6,9 \%$ & $4,2 \%$ & $6,9 \%$ & $6,1 \%$ & $10,3 \%$ \\
4 Ređe & $14,1 \%$ & $14,0 \%$ & $21,7 \%$ & $14,1 \%$ & $16,1 \%$ & $15 \%$ \\
5 Nikad & $71,0 \%$ & $73,1 \%$ & $65,8 \%$ & $64,7 \%$ & $68,8 \%$ & $59,8 \%$ \\
\hline $\begin{array}{l}\text { Srednja vrednost } \\
\text { indikatora (1-5) }\end{array}$ & 4,45 & 4,53 & 4,47 & 4,26 & 4,43 & 4,17 \\
\hline
\end{tabular}

Izvor: Eurofound, Third European Quality of Life Survey, 2012

karakterišu kao učvršćujuće veze, koje jačaju odnose unutar homogenih grupa i obezbeđuju pomoć i podršku u prevazilaženju problema materijalnog i nematerijalnog karaktera. U Tabelama 2 i 3 prikazani su podaci o tome koliko se građani RS oslanjanju na lične, neformalne kontakte u rešavanju važnih životnih problema. Na osnovu prikazanih podataka, može se konstatovati da pojedinci koji žive u balkanskim zemljama visoko vrednuju odnose sa prijateljima i porodicom i oslanjanju se na njihovu podršku tokom svog života u mnogo većem obimu u odnosu na građane
EU. Obrnuto, u zemljama EU građani se češće odlučuju da pomoć ili podršku potraže od zvaničnih institucija, dok se u RS mali procenat oslanja na institucionalne kapacitete za rešavanje problema nezaposlenosti, finansijskih i drugih ličnih ili porodičnih problema. Na primer, čak 73,6\% građana RS oslanja se na pomoć porodice ili prijatelja u traženju posla, dok samo $9,2 \%$ koristi usluge zvaničnih institucija.

Empirijski podaci ukazuju na to da su se građani RS i zemalja regiona, u godinama ekonomskih i političkih

Tabela 2 Neformalne mreže: Podrška/pomoć u traženju posla

\begin{tabular}{l|cccccc}
\hline & Republika Srbija & BJR Makedonija & Crna Gora & Hrvatska & Prosek Balkan & Prosek EU 27 \\
\hline $\begin{array}{l}\text { Član porodice ili } \\
\text { rođak }\end{array}$ & $42 \%$ & $44,9 \%$ & $63,7 \%$ & $34,2 \%$ & $46,2 \%$ & $30,6 \%$ \\
$\begin{array}{l}\text { Prijatelj, komšija } \\
\text { ili neko drugi }\end{array}$ & $31,6 \%$ & $27,2 \%$ & $22,5 \%$ & $31,6 \%$ & $28,3 \%$ & $24,6 \%$ \\
$\begin{array}{l}\text { Pružalac usluga, } \\
\text { institucija }\end{array}$ & $9,2 \%$ & $17,8 \%$ & $5,5 \%$ & $14 \%$ & $11,6 \%$ & $23,1 \%$ \\
Niko & $17,2 \%$ & $10,1 \%$ & $8,3 \%$ & $20,1 \%$ & $13,9 \%$ & $21,8 \%$ \\
\hline
\end{tabular}


Tabela 3 Neformalne mreže: Hitna pozajmica novca

\begin{tabular}{l|cccccc}
\hline & Republika Srbija & BJR Makedonija & Crna Gora & Hrvatska & Prosek Balkan & Prosek EU 27 \\
\hline $\begin{array}{l}\text { Član porodice ili } \\
\text { rođak }\end{array}$ & $63,0 \%$ & $68,5 \%$ & $81,4 \%$ & $70,7 \%$ & $70,9 \%$ & $69,4 \%$ \\
$\begin{array}{l}\text { Prijatelj, komšija } \\
\text { ili neko drugi }\end{array}$ & $28,4 \%$ & $22,4 \%$ & $15,6 \%$ & $20,0 \%$ & $21,6 \%$ & $11,9 \%$ \\
$\begin{array}{l}\text { Pružalac usluga, } \\
\text { institucija }\end{array}$ & $2,2 \%$ & $3,9 \%$ & $0,5 \%$ & $3,6 \%$ & $2,6 \%$ & $9,2 \%$ \\
Niko & $6,4 \%$ & $5,3 \%$ & $2,5 \%$ & $5,7 \%$ & $4,9 \%$ & $9,6 \%$ \\
\hline
\end{tabular}

Izvor: Eurofound, Third European Quality of Life Survey, 2012

promena nakon tranzicije, okrenulijačanju neformalnih društvenih veza, tražeći spas u društvenim nišama sastavljenim od bliskih rođaka i prijatelja. Dakle, proces tranzicije $\mathrm{u}$ balkanskim zemljama uticao je na to da se kreiranje društvenog kapitala usmeri u pravcu opstajanja i jačanja neformalnih mreža, tj. očuvanja karakteristika društvenog kapitala iz socijalističkog perioda. Opstajanje neformalnih mreža, kao glavnih poluga za rešavanje svakodnevnih životnih problema, praćeno je sporim razvojem širih formalnih mreža.

\section{Poverenje kao kvalitativni aspekt društvenog kapitala}

Merenje nivoa generalizovanog poverenja zasnovano je na odgovorima ispitanika na pitanje „Da li biste rekli da se većini ljudi može verovati?", gde se ispitanici opredeljuju za jedan broj na skali od 1 („Mora se biti oprezan“) do 10 („Većini ljudi se može verovati“). Podaci o nivou generalizovanog poverenja u RS, zemljama u okruženju i prosečnim vrednostima za EU27 prikazane su u Tabeli 4.

Emprijski podaci ukazuju na nizak nivo generalizovanog poverenja u RS - samo 2,3\% ispitanika iz RS opredelilo se za broj 10, koji označava maksimalni stepen poverenja $u$ ljude uopšte. Procenat ispitanika koji veruju da se ljudima može verovati (zbir odgovora 6 - 10) je dva puta manji (33,5\%) u odnosu na procenat ispitanika (66,3\%) koji iskazuju nepoverenje (zbir odgovora 1-5). U poređenju sa rezultatima istraživanja u EU, uočava se veliki jaz u nivou poverenja. Ranija istraživanja poverenja ukazivala su na dugoročnu i hroničnu prirodu tog jaza, uz evidentnu tendenciju daljeg opadanja poverenja u tranzicionim zemljama, koja doprinosi produbljivanju razlika $\mathrm{u}$ nivou poverenja između razvijenih evropskih zemalja i zemalja $\mathrm{u}$ tranziciji. Nivoi poverenja $\mathrm{u}$ balkanskim zemljama su relativno ujednačeni, što ukazuje na slične uslove akumulacije društvenog kapitala. Jedan od statistički značajnih prediktora $($ sig $=0,0037)$ nivoa poverenja u RS jeste visina dohotka, $u$ smislu da ispitanici koji pripadaju nižim dohodovnim kvartilima iskazuju niži stepen poverenja u ljude uopšte.

Važan parametar društvenog kapitala u jednoj zemlji predstavlja i stepen poverenja građana $u$ institucije sistema. Indikator institucionalnog poverenja zasniva se na skalama procene poverenja ( $\mathrm{u}$ konkretnom slučaju od 1, što podrazumeva potpuno odsustvo poverenja, do 10, što označava puno poverenje) $u$ različite institucije. U Tabeli 5 prikazani su podaci

Tabela 4 Nivo generalizovanog poverenja (na skali od 1-10)

\begin{tabular}{l|c}
\hline Zemlja & Srednja vrednost indikatora \\
\hline Republika Srbija & 4,53 \\
BJR Makedonija & 3,54 \\
Crna Gora & 4,86 \\
Hrvatska & 4,59 \\
\hline Prosek Balkan & 4,38 \\
Prosek EU 27 & 5,03 \\
\hline
\end{tabular}

Izvor: Eurofound, Third European Quality of Life Survey, 2012 
Tabela 5 Poverenje $\mathrm{u}$ institucije (na skali od 1 -10)

\begin{tabular}{l|cccccc}
\hline Zemlja & Vlada & Skupština & Pravni sistem & Štampa & Lokalne vlasti & Policija \\
\hline Republika Srbija & 2,95 & 2,88 & 3,08 & 3,56 & 3,29 & 4,33 \\
BJR Makedonija & 4,18 & 3,90 & 4,00 & 3,93 & 4,06 & 4,66 \\
Crna Gora & 4,00 & 4,08 & 4,17 & 4,67 & 3,85 & 4,53 \\
Hrvatska & 3,32 & 2,96 & 3,15 & 3,54 & 3,33 & 4,66 \\
\hline Prosek Balkan & 3,61 & 3,46 & 3,60 & 3,93 & 3,63 & 4,55 \\
Prosek EU 27 & 4,05 & 4,05 & 4,76 & 4,47 & 5,30 & 5,91 \\
\hline
\end{tabular}

Izvor: Eurofound, Third European Quality of Life Survey, 2012

o prosečnom poverenju $u$ različite institucije $u$ RS, zemljama u regionu i evropskim zemljama.

Istraživanje poverenja $\mathrm{u}$ institucije $\mathrm{u}$ RS ukazuje na alarmantno nizak nivo poverenja građana, naročito u političke institucije (parlament, vlada). Nešto viši nivo poverenja uživaju institucije pravosudnog sistema i sistema zaštite, ali prema ovom pokazatelju, RS predstavlja državu koja uživa najmanje poverenja svojih građana, čak i u odnosu na zemlje iz neposrednog okruženja. Sa najnižim nivoom poverenja suočavaju se upravo institucije koje su od najvećeg značaja za funkcionisanje privrednog i političkog života (pravosuđe, vlada, parlament). Da je reč o nepoverenju građana prema svim, a ne pojedinačnim institucijama, potvrđuju i visoki koeficijenti korelacije između pokazatelja poverenja u pojedinačne institucije sistema (Tabela 6).

\section{Siva ekonomija kao prepreka u poslovanju}

Za merenje obima sive ekonomije $\mathrm{u}$ savremenim privredama koriste se različiti metodi, kao osnova za obima sive ekonomije izražene $\mathrm{u}$ vidu procenta bruto domaćeg proizvoda. Jedan od takvih metoda je MIMIC (Multiple Indicators, Multiple Causes), koji uzima u obzir višestruke uzroke i višestruke efekte sive ekonomije, predstavljajući najobuhvatniji metod merenja kako po sektorima (domaćinstva, preduzeća), tako i po aktivnostima. Postoje i metodi koji sivu ekonomiju mere na osnovu podataka o poštovanju poreskih propisa kod domaćinstava (HTC metod),

Tabela 6 Koeficijenti korelacije između indikatora poverenja u Republici Srbiji

\begin{tabular}{l|ccccc}
\hline & Skupština & Pravni sistem & Štampa & Policija & Vlada \\
\hline Pravni sistem & $0.766^{* *}$ & - & - & - & - \\
Štampa & $0.556^{* *}$ & $0.539^{* *}$ & - & - & - \\
Policija & $0.584^{* *}$ & $0.590^{* *}$ & $0.572^{* *}$ & - & - \\
Vlada & $0.806^{* *}$ & $0.721^{* *}$ & $0.604^{* *}$ & $0.627^{* *}$ & - \\
Lokalne vlasti & $0.690^{* *}$ & $0.634^{* *}$ & $0.566^{* *}$ & $0.544^{* *}$ & $0.760^{* *}$ \\
\hline
\end{tabular}

Napomena: ** $\mathrm{p}<0.01$

Izvor: Autori, na osnovu: Eurofound, Third European Quality of Life Survey, 2012 
gde se merenjem obuhvataju oni oblici sive ekonomije koji se mogu uočiti na osnovu dohotka i potrošnje domaćinstava. Procene obima sive ekonomije u RS prema pomenutim makroekonomskim modelima kreću se oko $30 \%$ bruto domaćeg proizvoda - 30,1\% prema MIMIC metodu i 23,6\% prema u 2010. godini prema HTC metodu (Krstić i ostali, 2013).

Zbog razlika u obuhvatu, oblicima sive ekonomije koji su predmet merenja i metodologiji procene postojećih modela merenja, njihovi rezultati se često dopunjuju anketiranjem predstavnika preduzeća, kako bi se iz njihovog ugla sagledao fenomen sive ekonomije i procenila rasprostranjenost njenih oblika u ovom sektoru. U tom smislu, u ovom radu kao pokazatelj sive ekonomije koristiće se percepcije predstavnika poslovne zajednice o nelojalnoj konkurenciji koja dolazi iz neformalnog sektora privrede, prikupljenih u okviru Istraživanja o poslovnom okruženju i učinku preduzeća tokom 2013. godine (EBRD, BEEPS V Report, 2015a).

Prema rezultatima ovog istraživanja, tri najznačajnije prepreke u poslovanju preduzeća u RS jesu politička nestabilnost, visina poreskih stopa i pristup finansijskim sredstvima (Tabela 7). Međutim, preko $10 \%$ preduzeća u uzorku kao ključni izazov sa kojim se suočavaju $u$ svom poslovanju ističe nelojalnu konkurenciju iz neformalnog sektora.

Da ovaj problem prevazilazi nacionalne, pa i regionalne granice, ukazuje činjenica da su preduzeća iz više od trećine zemalja obuhvaćenih istraživanjem istakla sivu ekonomiju kao glavnu prepreku u svom poslovanju (samo je 9 zemalja u kojima se siva ekonomija nije našla među tri najvažnije prepreke). Preko 40\% anketiranih preduzeća prijavilo je da se suočava sa nelojalnom konkurencijom iz neformalnog sektora. Pritom se pod sivom ekonomijom u ovom istraživanju ne podrazumeva samo poslovanje preduzeća koja nisu formalno registrovana, već i aktivnosti registrovanih preduzeća poput prikazivanja nižih prihoda, manjeg broja radnika ili nižih zarada, u cilju izbegavanja plaćanja poreza ili pribavljanja potrebne dokumentacije. Raspostranjenost neformalnih aktivnosti najuočljivija je u preduzećima čiji se promet uglavnom obavlja $u$ gotovini (male radnje, taksi službe), kao i u sektorima
Tabela 7 Najveće prepreke u poslovanju u Republici Srbiji

\begin{tabular}{l|cc}
\hline Najveća prepreka u poslovanju & $\begin{array}{c}\text { Broj } \\
\text { preduzeća }\end{array}$ \\
\hline Pristup finansiranju & 52 & 14,44 \\
Pristup zemljištu & 2 & 0,56 \\
Dozvole & 6 & 1,67 \\
Korupcija & 22 & 6,11 \\
Sudstvo & 18 & 5,00 \\
Kriminal & 12 & 3,33 \\
Carine i trgovinska regulativa & 14 & 3,89 \\
Električna energija & 3 & 0,83 \\
Nekvalifikovana radna snaga & 7 & 1,94 \\
Radno zakonodavstvo & 6 & 1,67 \\
Politička nestabilnost & 70 & 19,44 \\
Nelojalna konkurencija iz neformalnog & 39 & 10,83 \\
sektora & & \\
Poreska administracija & 17 & 4,72 \\
Poreske stope & 60 & 16,67 \\
Transport & 2 & 0,56 \\
n/a & 30 & 18,61 \\
\hline Ukupno & 360 & 100,00 \\
\hline
\end{tabular}

Izvor: EBRD, BEEPS V Report, 2015a

građevinarstva, poljoprivrede i usluga koje se pružaju domaćinstvima (EBRD, 2015a).

Različita preduzeća u RS imaju različite percepcije o sivoj ekonomiji - određene vrste preduzeća izložene su u većoj meri konkurenciji iz neformalnog sektora, poput malih preduzeća, preduzeća koja posluju kraće vreme, i onih koja posluju u malim mestima (Tabela 8).

Detaljniji podaci o percepcijama preduzeća o sivoj ekonomiji kao prepreci $u$ njihovom poslovanju prikazani su u Tabeli 9. Samo 40,83\% preduzeća nema problema sa konkurencijom iz neformalnog sektora, dok oko $6 \%$ preduzeća ukazuje da je to najozbiljnija prepreka u poslovanju. Trećina preduzeća smatra da poslovanje konkurentskih preduzeća iz neformalnog sektora privrede ugrožava njihov rad (zbir kategorija umerena, velika i veoma ozbiljna prepreka). 
Tabela 8 Karakteristike preduzeća koja sivu ekonomiju smatraju najvećom preprekom u poslovanju

\begin{tabular}{|c|c|c|}
\hline & & $\begin{array}{c}\text { Broj } \\
\text { preduzeća }\end{array}$ \\
\hline \multicolumn{3}{|l|}{ Veličina preduzeća } \\
\hline & Mikro & 2 \\
\hline & Mala & 22 \\
\hline & Srednja & 12 \\
\hline & \multirow[t]{2}{*}{ Velika } & 3 \\
\hline & & 39 \\
\hline \multicolumn{3}{|l|}{ Godine poslovanja } \\
\hline & Do 5 & 1 \\
\hline & $6-25$ & 38 \\
\hline & $26-50$ & 0 \\
\hline & \multirow[t]{2}{*}{ Preko 51} & 0 \\
\hline & & 39 \\
\hline \multicolumn{3}{|l|}{ Privredna grana } \\
\hline & Proizvodnja & 12 \\
\hline & Trgovina & 13 \\
\hline & \multirow[t]{2}{*}{ Ostale usluge } & 14 \\
\hline & & 39 \\
\hline \multicolumn{3}{|l|}{ Vlasništvo } \\
\hline & Privatni domaći kapital & 33 \\
\hline & Privatni strani kapital & 4 \\
\hline & Državni kapital & 0 \\
\hline & \multirow[t]{2}{*}{ Ostalo } & 2 \\
\hline & & 39 \\
\hline \multicolumn{3}{|l|}{ Region } \\
\hline & Beograd & 11 \\
\hline & Vojvodina & 11 \\
\hline & Šumadija i Zapadna Srbija & 13 \\
\hline & Južna i Istočna Srbija & 4 \\
\hline & & 39 \\
\hline \multicolumn{3}{|l|}{ Veličina lokaliteta } \\
\hline & Preko 1 milion (glavni grad) & 11 \\
\hline & 250000 do milion & 2 \\
\hline & $50000-250000$ & 10 \\
\hline \multirow{2}{*}{\multicolumn{2}{|c|}{ Manje od 50000}} & 16 \\
\hline & & 39 \\
\hline
\end{tabular}

Izvor: EBRD, BEEPS V Report, 2015a
Tabela 9 Percepcije o sivoj ekonomiji kao prepreci u poslovanju u Republici Srbiji

\begin{tabular}{l|cc}
\hline $\begin{array}{l}\text { Percepcija o sivoj ekonomiji } \\
\text { kao prepreci }\end{array}$ & Broj & $\%$ \\
\hline Nije prepreka & 147 & $40,83 \%$ \\
Manja prepreka & 71 & $19,72 \%$ \\
Umerena prepreka & 55 & $15,28 \%$ \\
Velika prepreka & 40 & $11,11 \%$ \\
Veoma ozbiljna prepreka & 21 & $5,83 \%$ \\
Ne znam & 5 & $1,39 \%$ \\
Bez odgovora & 21 & $5,83 \%$ \\
\hline Ukupno & 360 & $100 \%$ \\
\hline
\end{tabular}

Izvor: EBRD, BEEPS V Report, 2015a

Istraživanjem je ustanovljeno da se čak 45\% preduzeća u svom poslovanju susreće sa konkurentskim preduzećima iz neformalnog sektora. Više od $12 \%$ preduzeća ističe da je broj konkurenata iz neformalnog sektora toliki da ih je teško izbrojati. Samo 2,71\% preduzeća obuhvaćenih uzorkom ističe da nema konkurente. Prosečan broj konkurenata iz neformalnog sektora koji prijavljuju anketirana preduzeća je 16,87. U Tabeli 10 detaljnije su navedeni rezultati istraživanja o broju konkurenata iz neformalnog sektora privrede.

Tabela 10 Broj konkurenata iz neformalnog sektora

\begin{tabular}{l|cc}
\hline Broj konkurenata & $\mathrm{N}$ & $\%$ \\
\hline Nema konkurente & 9 & $2,71 \%$ \\
$1-5$ & 104 & $31,33 \%$ \\
$6-10$ & 72 & $21,69 \%$ \\
$10-50$ & 69 & $20,78 \%$ \\
$51-99$ & 6 & $1,81 \%$ \\
100 & 13 & $3,92 \%$ \\
Toliki da ih je teško prebrojati & 41 & $12,35 \%$ \\
Bez odgovora & 18 & $5,42 \%$ \\
\hline Ukupno & 332 & $100 \%$ \\
\hline
\end{tabular}

Izvor: EBRD, BEEPS V Report, 2015a 


\section{ZAKLJUČAK}

Metodološki problemi i nedoumice koji prate sve pokušaje merenja neopipljivih društvenih fenomena, poput poverenja, gustine društvenih mreža i rasprostranjenosti sive ekonomije $u$ jednoj privredi, predstavljaju jedno od suštinskih ograničenja $u$ istraživanju odnosa između društvenog kapitala i obima neformalnih transakcija. Ipak, savremena istraživanja ovih pojava dostigla su zadovoljavajući nivo objektivnosti i preciznosti, te danas predstavljaju osnov za donošenje validnih zaključaka o odnosima između navedenih pojava. Osnovni doprinos istraživanja $u$ ovom radu odnosi se na proširivanje analize potencijalnih uzroka sive ekonomije $u$ Republici Srbiji, ukazivanjem na karakteristike društvenih veza kao potencijalne determinante obima transakcija $\mathrm{u}$ neformalnom sektoru privrede. Na osnovu istraživanja korišćenih u ovom radu, može se tvrditi da se stanovništvo i privreda RS suočavaju sa nekoliko ozbiljnih izazova.

Pre svega, podaci o društvenim odnosima ukazuju na to da je razvoj društvenog kapitala u RS u godinama intenzivnih ekonomskih i političkih promena tokom tranzicije išao $u$ pravcu razgradnje generalizovanog poverenja, poverenja $u$ institucije $i$ participacije $u$ formalnim društvenim mrežama. Nepoverenje prema ljudima uopšte i osećaj da se ne mogu osloniti na formalne institucije sistema, uticale su na građane Srbije da neguju neformalne društvene veze $\mathrm{i}$ specifičan tip poverenja karakterističan za homogene, zatvorene grupe. Specifičnosti društvenog kapitala $\mathrm{u}$ Srbiji ogledaju se $\mathrm{u}$ tome što snažne neformalne mreže nasleđene iz perioda pre tranzicije, nastale kao supstitut za funkcionalne formalne sisteme u uslovima neizvesnosti i nestašica, opstaju i danas.

Snažne neformalne mreže i partikularizovano poverenje često se $\mathrm{u}$ teoriji društvenog kapitala označavaju kao negativan društveni kapital, s obzirom da ovakva vrsta društvenih veza i odnosa olakšava realizaciju društveno nepoželjnih aktivnosti - kriminala, korupcije, sive ekonomije. Procene obima sive ekonomije iz ugla preduzeća ukazuju da je neformalni sektor privrede rasprostranjen toliko da predstavlja relevantnu prepreku $\mathrm{u}$ poslovanju preduzeća u RS. Nelojalna konkurencija formalno neregistrovanih preduzeća, ali i aktivnosti registrovanih preduzeća usmerenih na zaobilaženje pravila ili izbegavanje finansijskih obaveza prema državi, predstavlja dodatni problem preduzećima u zemlji koja se, prema međunarodnim standardima, smatra nisko konkurentnom privredom.

Uvažavajući dejstvo institucionalnih faktora koji omogućavaju razvoj sive ekonomije (poreskog opterećenja, stepena regulacije privrede, kapaciteta državne uprave), koji nisu bili predmet analize u ovom radu, na osnovu iznetih podataka o društvenom kapitalu i sivoj ekonomiji u RS može se zaključiti da, u skladu sa polaznim pretpostavkama, visok nivo međusobnog poverenja i odsustvo poverenja $u$ institucije podstiču rast sive ekonomije.

Zaključci izneti u radu upućuju na potrebu daljeg ispitivanja obima sive ekonomije $\mathrm{u}$ RS, kao i utvrđivanja kvantitativnih odnosa između pojedinačnih elemenata društvenog kapitala i rasprostranjenosti sive ekonomije. U cilju otkrivanja ključnih uzroka i faktora koji pospešuju intezitet neformalnih transakcija, neophodno je sivu ekonomiju sagledati u okviru sveobuhvatnih modela koji će utvrditi specifičan značaj kako institucionalnih uslova, tako i društvenih determinanti sive ekonomije.

\section{ZAHVALNICA}

Ovaj rad je deo Projekta osnovnih istraživanja (br. 179066), koji finansira Ministarstvo prosvete, nauke i tehnološkog razvoja Republike Srbije.

\section{REFERENCE}

Burroni, L., Crouch, C., Kaminska, M., \& Valzania, A. (2008). Local Economic Governance in Hard Times: The Shadow Economy and the Textile and Clothing Industries around Łodz and Naples. Socio-Economic Review, 6(2), 473-492. doi: 10.1093/ser/mwn005

Busse, S. (2001). Strategies of Daily Life: Social Capital and the Informal Economy in Russia. Sociological Imagination, 38(3), 166-189. 
Castells, M. (1997). The power of identity. MA, USA and Oxford, UK: John Wiley \& Sons, Ltd., Publication.

Coleman, J. (1990). Foundations of Social Theory. Cambridge, MA, USA: The Belknap Press of Harvard University Press.

Dasgupta, P. (2000). Economic progress and the idea of social capital. In P. Dasgupta and I. Serageldin (Eds.). Social capital: A multifaceted perspective (pp. 325-424). Washington D.C. USA: World Bank.

De Soto, H. (2000). The Mystery of Capital: Why Capitalism Triumphs in the West and Fails Everywhere Else. New York, NY: Basic Books.

Eurofound. (2012). Third European Quality of Life Survey, 20112012. [computer file]. 2nd Edition. Colchester, Essex: UK Data Archive [distributor]. Retrieved January 2014, SN: 7316, from http://dx.doi.org/10.5255/UKDA-SN-7316-2

European Bank for Reconstruction and Development (EBRD). (2015). Business Environment and Enterprise Performance Survey. Retrieved August 31, 2015, from http://ebrd-beeps. com/data/

European Bank for Reconstruction and Development (EBRD). (2015a). The Business Environment in the Transition Region. BEEPS V Report. Retrieved September 4, 2015 http://ebrdbeeps.com/reports/beeps_v_report/

Field, J. (2003). Social Capital. London, UK and New York, NY: Routledge.

Flap, H., \& Volker, B. (2003). Communist Societies, the Velvet Revolution, and Weak Ties: The Case of East Germany. In G. Badescu, and E. Uslaner, (Eds.). Social Capital and the Transition to Democracy. London, UK: Routledge.

Fukuyama, F. (1995). Trust: The Social Virtues and the Creation of Prosperity. London, UK: Hamish Hamilton.

Fukuyama, F. (2000). Social Capital and Civil Society. Working Paper 00/74, Washington D.C. USA: International Monetary Fund.

Grossman, G. (1989). Informal Personal Incomes and Outlays of the Soviet Urban Population, In A. Portes, M. Castells, \& L. Benton (Eds.), The Informal Economy: Studies in Advanced and Less Developed Countries (pp. 150-170). Baltimore, MD: Johns Hopkins University Press.

Johnson, S., Kaufmann, D., \& Zoido-Lobatón, P. (1998). Regulatory Discretion and the Unofficial Economy. American Economic Review, 88(2), 387-392.

Kloosterman, R., van der Leun, J. \& Rath, J. (1999). Mixed embeddedness: (In)formal Economic and Immigrant Business in the Netherlands. International Journal of Urban and Regional Research, 23(2), 252-266.

Krstić, G., Schneider, F., Arandarenko, M., Arsić, M., Radulović, B., Ranđelović, S. i Janković, I. (2013). Siva ekonomija u Srbiji: Novi nalazi i preporuke za reforme. Beograd, Republika Srbija: Fondacija za razvoj ekonomske nauke.

Ledeneva, A. (1998). Russia's Economy of Favours: Blat, Networking, and Informal Exchanges. New York, NY: Cambridge University Press.

Lekovic, V. (2012). Trust as an institutional factor of economic success. Economic Horizons, 14(2), 65-78. doi: 10.5937/ ekonhor1202063L

Levy, S. (2008). Good Intentions, Bad Outcomes: Social Policy, Informality, and Economic Growth in Mexico. Washington D.C. USA: Brookings Institution Press.

McKinsey (2004). The Hidden Dangers of the Informal Economy. McKinsey Quarterly, 3, 27-37. http://immagic.com/ eLibrary/ARCHIVES/GENERAL/MCKNSYUS/M040413F. pdf

Millar, J. (Ed.). (1987). Politics, Work and Daily Life in the USSR: A survey of former Soviet citizens. Cambridge, USA: Cambridge University Press.

Portes, A. (1994). The Informal Economy and its Paradoxes. In N. Smelser, \& R. Swedberg (Eds.), The Handbook of Economic Sociology (pp. 426-449). Princeton, USA: Princeton University Press.

Portes, A. (Ed.). (1995). The Economic Sociology of Immigration: Essays on Networks, Ethnicity and Entrepreneurship. New York City, NY: Russell Sage.

Portes, A. (1998). Social Capital: Its Origins and Applications in Modern Sociology. Annual Review of Sociology, 24(1), 1-24.

Portes, A. (2010). Economic Sociology: A Systematic Inquiry. Princeton, USA: Princeton University Press.

Portes, A., \& Landolt, P. (1996). The downside of social capital. The American Prospect, 7(26), 18-21.

Schneider, F., Buehn, A., \& Montenegro, C. E. (2010). Shadow Economies All over the World. New Estimates for 162 Countries from 1999 to 2007. Washington D.C. USA: World Bank.

Thomas, J. (1992). Informal Economic Activity. New York, NY: Harvester.

Van Deth, J. (2003). Measuring Social Capital: Orthodoxies and Continuing Controversies. International Journal of Social Research Methodology, 6(1), 79-92. DOI: 10.1080/13645570210156040 
Primljeno 10. novembra 2015, nakon revizije, prihvaćeno za publikovanje 15. decembra 2015.

Elektronska verzija objavljena 25. decembra 2015.

Nataša Golubović je redovni profesor na Ekonomskom fakultetu Univerziteta u Nišu. Doktorsku disertaciju odbranila je na Ekonomskom fakultetu Univerziteta u Beogradu. Izvodi nastavu iz nastavnih predmeta Osnovi ekonomije, Politička ekonomija, Društvena ekonomika i Ekonomika javnog izbora. U naučnoistraživačkom radu, polja njenog interesovanja su ekonomska analiza politike i institucionalna analiza. Autor je udžbenika, monografija i članaka objavljenih u domaćim i međunarodnim časopisima. Učestvovala je na brojnim naučnim skupovima.

Marija Džunić je vanredni profesor na Ekonomskom fakultetu Univerziteta u Nišu, na Katedri za Opštu ekonomsku teoriju. Doktorsku disertaciju je odbranila na Ekonomskom fakultetu Univerziteta u Beogradu. Predaje predmete Osnovi ekonomije, Politička ekonomija, Društvena ekonomika i Ekonomika javnog izbora. Bavi se društvenim kapitalom i ekonomskim rastom. Objavila je brojne radove u časopisima nacionalnog i međunarodnog značaja, i učestvovala na međunarodnim i domaćim konferencijama. 


\title{
SOCIAL CAPITAL AS A DETERMINANT OF THE SHADOW ECONOMY IN THE REPUBLIC OF SERBIA
}

\author{
Natasa Golubovic and Marija Dzunic \\ Faculty of Economics, University of Nis, Nis, the Republic of Serbia
}

\begin{abstract}
The design and implementation of the measures aimed at incorporating informal economic activities into the existing formal regulatory framework assume the knowledge of the causes and structure of the informal activity. The influence of the institutional factors that encourage the development of the shadow economy (the tax burden, the degree of the regulation of the economy, the capacity of the state administration) were the subject of extensive theoretical and empirical research. In contrast, the impact of social capital, i.e. the characteristics of social ties and relations, on the shadow economy has been investigated to a much lesser extent. Starting from the fact that the informal sector of the Serbian economy is so widespread that it represents a serious obstacle to the business activities of Serbian enterprises, the aim of this study is to investigate whether the characteristics of social ties and relations, or social capital in the Republic of Serbia (RS), represent a fertile ground for the growth of the shadow economy. In this context, the characteristics and frequency of social contacts, particularized trust and institutional trust will be separately analyzed as the determinants of the shadow economy in RS.
\end{abstract}

Keywords: social capital, social networks, trust, shadow economy

JEL Classification: E26, O17, Z13 